\title{
Studiu privind percepția studenților la Drept asupra pedepsei cu moartea ${ }^{1}$
}

\author{
Lector univ. dr. Andra - Roxana TRANDAFIR, \\ Asist. univ. dr. Dragoș PÂRGARU, \\ Drd. Valentina DINU, Drd. Florin BOBEI, \\ Facultatea de Drept, Universitatea din București
}

Rezumat: Prezentul articol explorează subiectul pedepsei cu moartea și argumentele aduse în favoarea și împotriva pedepsei capitale din perspectiva unui chestionar adresat studenților la Drept din facultățile ce alcătuiesc Hexagonul Facultăților de Drept. Fără a avea pretențiile unui studiu sociologic complet, datele privind cele 2201 de persoane care au participat prin răspunsuri la chestionar, precum și răspunsurile oferite intrebărilor esențiale oferă o imagine nouă și particulară în legătură cu percepțiile asupra pedepsei cu moartea întrun stat în care, într-adevăr, o reintroducere a acestei pedepse este, în acest moment, imposibilă. De asemenea, am procedat la o analiză a motivelor care determină studenții la Drept să se poziționeze în favoarea sau impotriva pedepsei cu moartea, având în vedere necesitatea relevării, din timp în timp, nu numai a procentului persoanelor care se declară în favoarea pedepsei cu moartea, ci și a principalelor argumente care reprezintă nucleul discuţiei la un anumit moment în cursul istoriei.

Cuvinte-cheie: pedeapsa cu moartea, studiu de opinie, pedepse, funcțiile pedepselor

\section{Study on the perception of law students on death penalty}

Abstract: This article explores the topic of the death penalty and the arguments for and against it from the perspective of a questionnaire addressed to law students coming from the faculties belonging to the Law Faculties Hexagon in Romania.. Without claiming to be a complete sociological study, the data regarding the 2201 respondents to the questionnaire, as well as the answers to the essential questions, provide a new and particular picture on perceptions regarding the death penalty in a country where, indeed, a reintroduction of this punishment is, at this time, impossible. We also carried out an analysis of the reasons that determine law students to position themselves in favor of or against the death penalty, given the need to reveal, from time to time, not only the percentage of people who declare themselves in favor of the death penalty, but also of the main arguments that represent the core of the discussion at a certain point in the course of history.

Key words: the death penalty, opinion polls, punishments, the functions of punishments

\footnotetext{
${ }^{1}$ Autorii doresc să mulțumească domnului prof. univ. dr. Valerian Cioclei pentru sprijinul acordat în conceperea chestionarului, precum și colegilor din Facultățile de Drept din cadrul Hexagonului care au ajutat la transmiterea chestionarului: conf. univ. dr. Laura Stănilă, conf.univ. dr. Stela Botnaru, asist. univ. dr. Ioana Curt, asist. univ. dr. Oana Bugnar, lector univ. dr. Elisabeta Boitan, lector univ. dr. Mihai Dunea, lector. univ. dr. Cătălin Voiculescu.
} 


\section{INTRODUCERE}

De-a lungul istoriei, în susţinerea abolirii pedepsei cu moartea, au fost aduse argumente numeroase. De asemenea, în diferite momente istorice ale dezbaterii, altele au fost argumentele folosite în mod preponderent. Bunăoară, când, în secolul XIX, Parlamentul olandez a luat în discuție în mod repetat potențiala abolire a pedepsei cu moartea, principalul argument invocat a fost unul de natură religioasă. Citate din Noul Testament au fost folosite atât de susținătorii pedepsei cu moartea, cât și de cei care militau în sensul abolirii acesteia. ${ }^{2} \mathrm{Cu}$ siguranță, dacă astăzi aceeași dezbatere ar avea loc în același organ legislativ, având în vedere caracteristicile generale ale societății olandeze contemporane, argumentul de natură religioasă ar fi mult mai puțin adus în discuție.

Societatea se dezvoltă în chip natural și, împreună cu această dezvoltare, argumentele în favoarea sau împotriva pedepsei capitale se modifică și ele. Diferențele de perspectivă între populația generală și legiuitor trebuie să fie minimizate pe cât posibil pentru a se păstra armonia socială. În măsura în care asemenea discrepanțe apar, ele trebuie să fie înțelese și corectate. În acest demers, unul dintre cele mai importante exerciții ce trebuie parcurse din timp în timp este reprezentat de revizuirea argumentelor care stau la baza poziționării într-o tabără sau alta întrun subiect ce nu suportă o a treia opțiune, astfel cum este cel ce face obiectul prezentului studiu.

A cunoaște motivele generale ale majorității ce se declară împotriva pedepsei cu moartea reprezintă un temei al oricărei discuții purtate cu cei care solicită reintroducerea acestei forme de sancționare.

La cea de-a treizecea aniversare a abolirii pedepsei cu moartea în România ${ }^{3}$, ne-am propus să identificăm aceste motive prin intermediul unui chestionar aplicat în rândul studenților la Drept. Astfel, am pornit de la un chestionar folosit anterior în cadrul seminarelor de criminologie de la Facultatea de Drept a Universităţii din București, pe care 1-am reconfigurat în luna martie 2020 și 1-am adaptat pentru a putea fi utilizat în mod electronic, prin intermediul Google Forms. Studenții acestei facultăţi au răspuns întrebărilor adresate în perioada 6-12 aprilie 2020. Ulterior, în perioada 16 aprilie-30 mai 2020, au răspuns studenţii de la facultățile de Drept ale universităților de stat din Cluj, Craiova, Iași, Sibiu, Timișoara și Chișinău. Am obținut un total de 2201 de răspunsuri, ceea ce reprezintă un eșantion relevant pentru a putea face aprecieri privind percepția acestor studenți asupra pedepsei cu moartea.

Am încercat să avem de asemenea un grup de control pentru a vedea dacă studenții la Drept se constituie într-o categorie diferită de respondenți, însă, în ciuda demersurilor efectuate, nu am obținut decât 46 de răspunsuri de la studenții altor facultăţi din cadrul Universităţii din București. Având în vedere numărul mic al acestor respondenți, prezentul studiu nu va avea, așadar, în vedere, aceste răspunsuri decât acolo unde ele prezintă particularități.

\footnotetext{
${ }^{2}$ Pentru mai multe detalii, a se vedea Lydia Bertram, Imprisonment as an alternative to the death penalty. Historical observations complementary to an emerging discussion, în lucrarea Beyond the death penalty. Reflections on punishment, Hans Nelen, Lacques Claessen (coordonatori), edit. Intersentia, Cambridge, 2012, pag. 63-75.

${ }^{3}$ Pedeapsa cu moartea a fost abolită prin Decretul-lege nr. 6 din 7 ianuarie 1990.
} 
Vom prezenta rezultatele chestionarului în cele ce urmează, arătând, într-o primă etapă, datele generale privind respondenții (I), pentru a putea vedea, apoi, opinia acestora privind aplicarea pedepsei cu moartea (II).

\section{DATE GENERALE PRIVIND RESPONDENȚII}

Așa cum am menționat, chestionarul a debutat cu o primă parte care a avut ca obiectiv cunoașterea datelor generale ale respondenților. Aceștia au trebuit să răspundă la întrebări privind anul de studiu (1), sex (2), vârstă (3), forma de învățământ (4) și facultatea de proveniență (5).

\section{Anul de studiu}

O primă întrebare a vizat anul de studiu în care sunt respondenții. Dintre cei 2201 de studenți care au răspuns, 396 sunt anul I (17.99\%), 663 sunt anul II (30.12\%), 561 sunt anul III (25.49\%), 375 sunt anul IV (17.04\%) și 190 sunt masteranzi (8.63\%). Un număr de 16 respondenți sunt studenți-doctoranzi $(0.73 \%)$. Rezultă așadar că aproape $93 \%$ dintre respondenți nu au absolvit încă facultatea. Situația grafică este redată mai jos în figura 1, iar numărul mare de respondenți din anul al II-lea se poate explica prin aceea că disciplina Criminologie, în cadrul căreia au loc discuții inclusiv despre pedeapsa cu moartea, se studiază, în general, în acest an.

Fig. 1. Procentul respondenților în funcție de anul de studiu

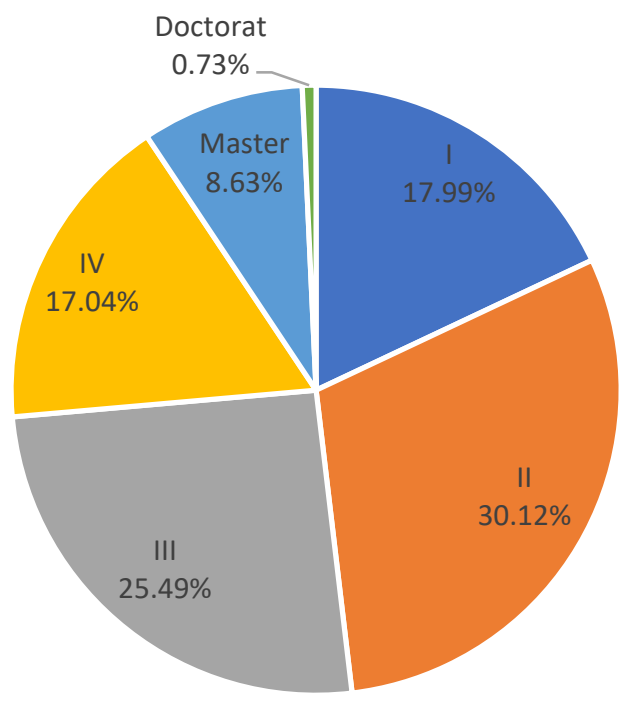




\section{Sex}

Distribuția respondenților în funcție de sex este redată în graficul de mai jos (figura 2). Se constată că numărul femeilor (1693) este de peste 3 ori mai mare decât cel al bărbaților (508).

\section{Fig. 2. Procentul respondenților în funcție de sex}

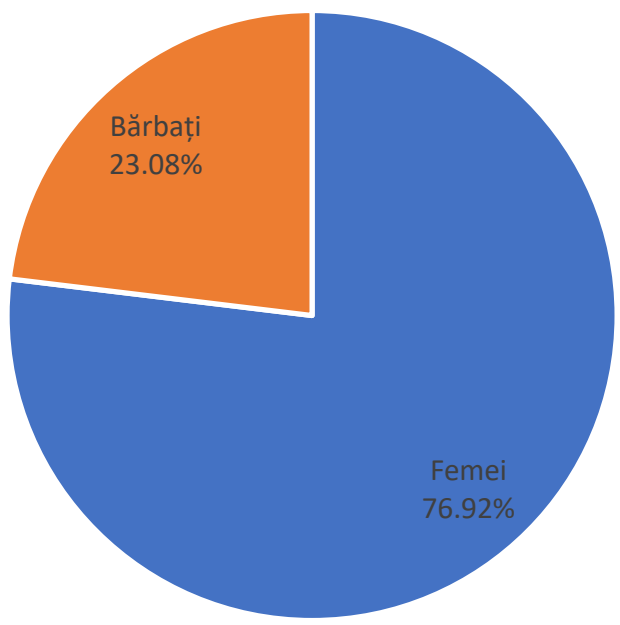

Deși aceste date pot părea surprinzătoare, ele sunt, în principiu, concordante cu cele privind distribuția studenților în cadrul facultăţilor de Drept. De exemplu, la Facultatea de Drept a Universității din București, la începutul anului universitar 2019-2020 erau 2786 de femei (71.62\% din total) și 1104 de bărbați $(28.38 \%)$.

\section{Vârstă}

Așa cum este firesc având în vedere anul de studiu, majoritatea respondenților se regăsesc în categoria de vârstă 20-21 de ani, urmată îndeaproape de vârsta de 22 de ani și cea de 19 ani. Numărul de respondenți pentru fiecare categorie este redat în graficul de mai jos (figura 3). 
Fig. 3. Numărul respondenților în funcție de vârstă

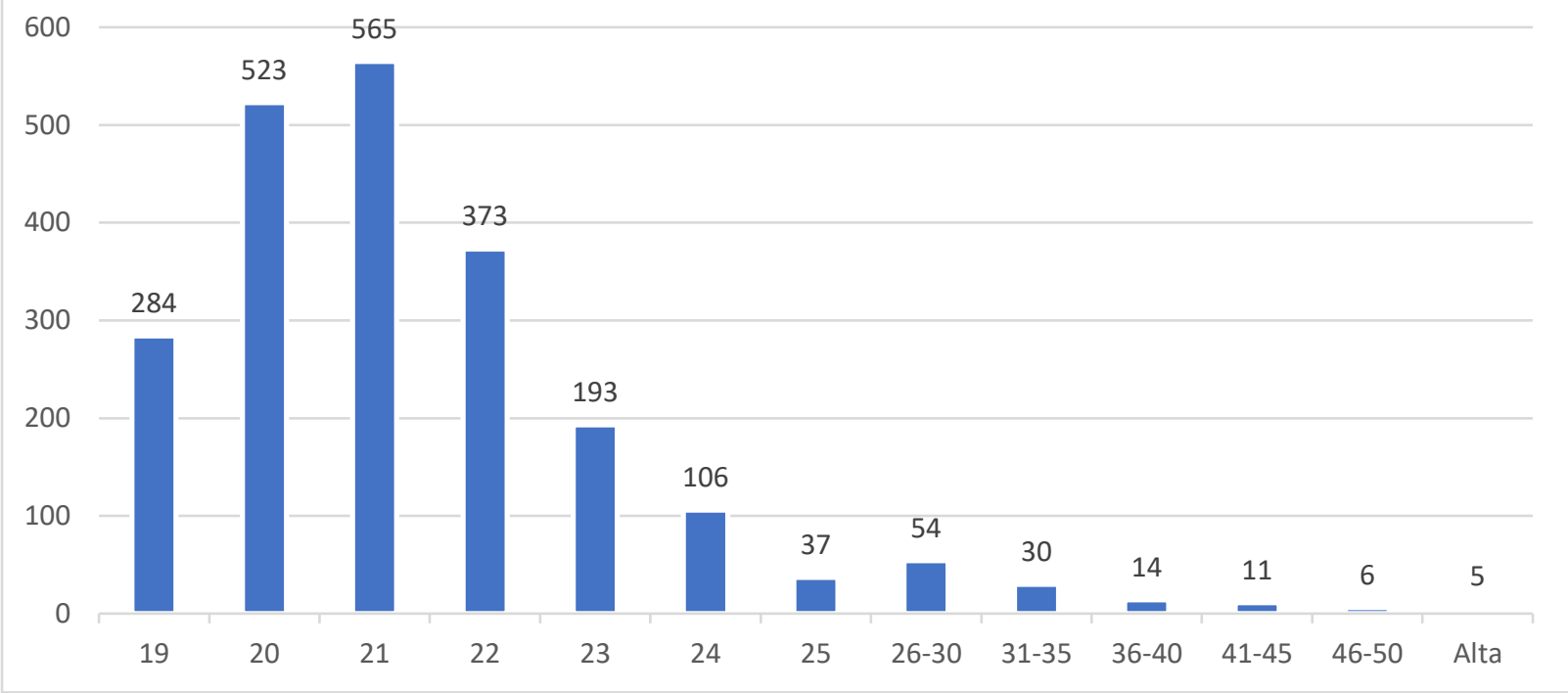

De asemenea, în cele ce urmează, în figura 4, este redat în format grafic procentul respondenților în funcție de vârstă. Se poate afirma așadar că studiul are în vedere în special percepția tinerilor cu vârsta cuprinsă între 19-23 de ani aspra pedepsei cu moartea, aceștia reprezentând aprox. 89\% dintre respondenți. Dacă adăugăm și procentul respondenților cu vârsta de 24 de ani, rezultă că aprox. 94\% dintre opinii au fost exprimate de tineri sub 25 de ani.

Fig. 4. Procentul respondenților în funcție de vârstă

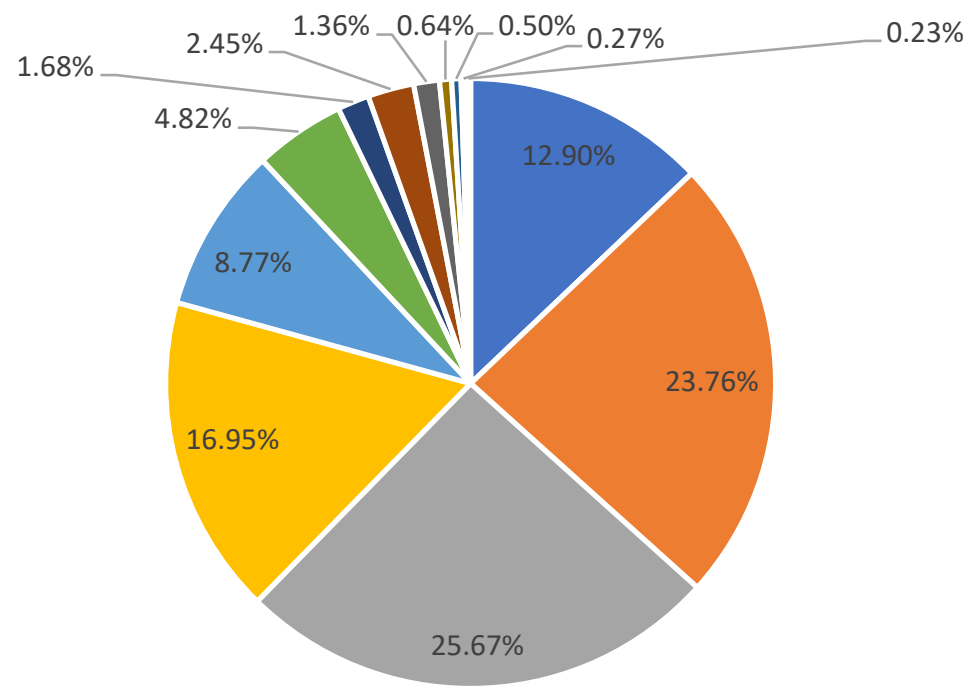




\section{Forma de învățământ}

În ceea ce privește forma de învățământ, cea mai mare parte dintre respondenți (1838, reprezentând un procent de 83.51) sunt studenți la învățământ cu frecvență. Un număr de 115 studenți (5.22\%) sunt la învățământ la distanță, iar 42 (1.91\%) - la învățământ cu frecvență redusă $\breve{4}^{4}$ O parte dintre respondenți $(9.36 \%)$ nu au oferit un răspuns la această întrebare. Situația grafică este redată mai jos, în figura 5. Datele astfel calculate reflectă, în mare măsură, distribuția studenților în cadrul facultăților participante la studiu. De pildă, în cadrul Facultății de Drept a Universității din București, 79,69\% dintre studenții din toți anii de studiu sunt studenți la învățământ cu frecvență.

\section{Fig. 5. Procentul respondenților în funcție de forma de învățământ}

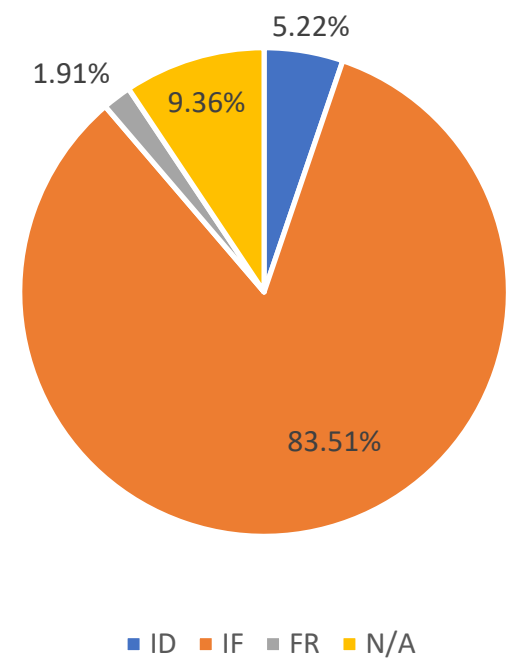

\section{Facultatea de proveniență}

Așa cum am arătat, respondenții provin de la cele şase facultăți care fac parte din Hexagonul Facultăților de Drept, precum și de la Facultatea de Drept a Universității de Stat din Moldova, entitate asociată acestui consorțiu. Distribuția studenților în funcție de facultatea de proveniență este redată în graficul de mai jos (figura 6), cu mențiunea că procentul de 5.95, corespunzând unui număr de 131 de respondenți care nu au indicat facultatea de proveniență, aparține tot facultăţilor de Drept din Hexagon. Rezultă așadar că $48.75 \%$ dintre respondenți provin de la Facultatea de Drept a Universității din București, iar 51.25\% provin de la celelalte şase facultăți.

Desigur, numărul mare de studenți ai Facultății de Drept a Universității din București poate fi ușor de explicat, prin aceea că cifra de școlarizare este cea mai mare dintre toate cele șapte facultă̆ți, dar și pentru că autorii prezentului studiu sunt cadre didactice titulare ori asociate

\footnotetext{
${ }^{4}$ Această formă de învățământ nu există la toate programele de studii sau/și la toate facultățile participante.
} 
la această facultate, rugămintea de completare a chestionarului fiindu-le adresată studenților și în cadrul cursurilor și seminarelor de criminologie.

Fig. 6. Procentul respondenților în funcție de facultatea de proveniență

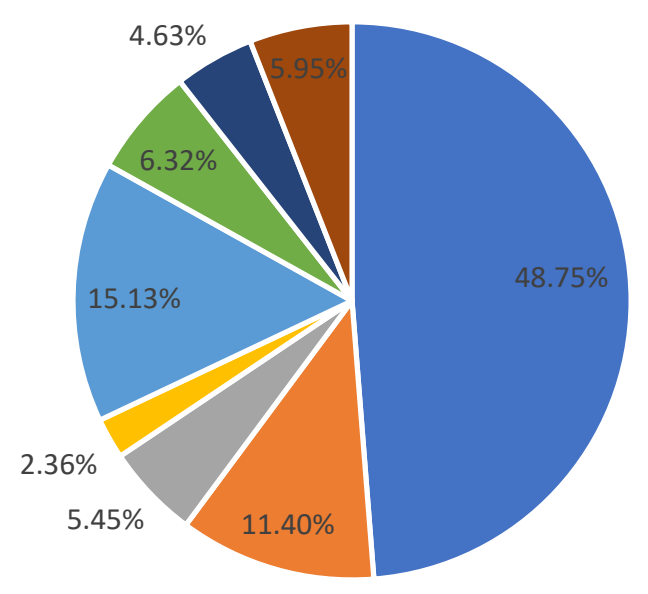

- București

- Cluj

- Craiova

- Chișinau

- Iași

- Sibiu

- Timișoara

- N/A

Din datele de mai sus, rezultă că profilul respondentului este acela al unui tânăr student la Drept, programul de studiu licență și învățământ cu frecvență, cu vârsta între 19-23 de ani, de regulă femeie.

\section{OPINIA PRIVIND APLICAREA PEDEPSEI CU MOARTEA}

După o primă secțiune privind datele generale despre respondenți, chestionarul a continuat cu aflarea opiniei acestora privind aplicarea pedepsei cu moartea. Întrebarea a avut forma „Sunteți de acord cu aplicarea pedepsei cu moartea?”, iar răspunsurile posibile au fost „Da” și „,Nu, în nicio situaţie”, pentru a sugera că orice excepție privind inaplicabilitatea pedepsei cu moartea trebuia încadrată în varianta „Da”. 69.42\% dintre respondenți (un număr de 1528) s-au declarat împotriva pedepsei cu moartea (dar, aşa cum vom vedea, acest procent este în realitate mai mic), iar 30.58\% (corespunzând unui număr de 673 de studenți) au ales varianta potrivit cu care sunt de acord cu aplicarea pedepsei cu moartea, așa cum rezultă și din graficul de mai jos (figura 7). Doar spre comparație, din cei 46 de studenţi provenind de la alte facultăţi din cadrul Universității din București, 54.3\% s-au arătat în favoarea pedepsei cu moartea, ceea ce poate sugera deja că susținerea pentru această pedeapsă poate fi, în realitate, mult mai mare, în rândul populaţiei generale. Această ipoteză va fi discutată și în cele ce urmează, în cadrul analizei opiniei privind aplicarea pedepsei cu moartea. 
Fig. 7. Opinia privind aplicarea pedepsei cu moartea

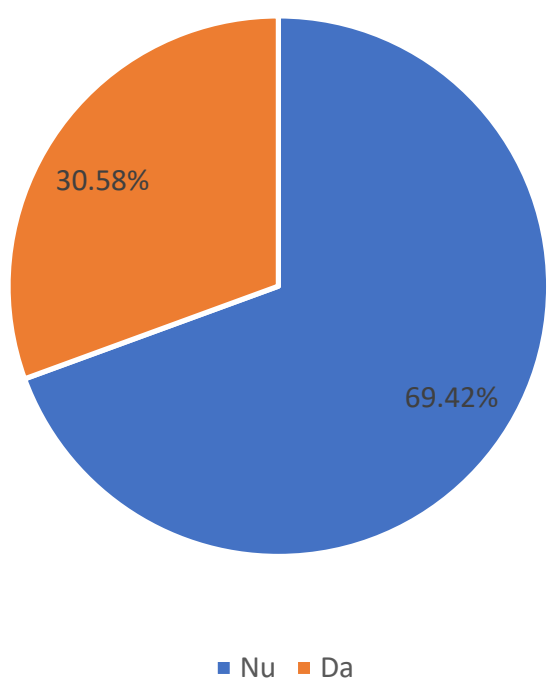

Răspunsurile la această întrebare sunt diferite în funcție de facultatea de proveniență. Redăm, în cele ce urmează, astfel cum pot fi observate și în figura 8, procentele calculate pentru fiecare facultate la întrebarea „Da”. Astfel, cel mai mic procent (27.6\%) există la Facultatea de Drept a Universității din București, singura care se află sub media răspunsurilor obținute la această întrebare, iar cel mai mare (45.83\%), la Facultatea de Drept a Universitătii din Craiova, urmată de Facultatea de Drept a Universității de Stat din Moldova (38.46\%), Facultatea de Drept a Universității „Lucian Blaga” din Sibiu (35.25\%), Facultatea de Drept a Universității Babeș Bolyai din Cluj-Napoca (32.27\%) și Facultatea de Drept a Universității „Alexandru Ioan Cuza" din Iași (31.53\%). 


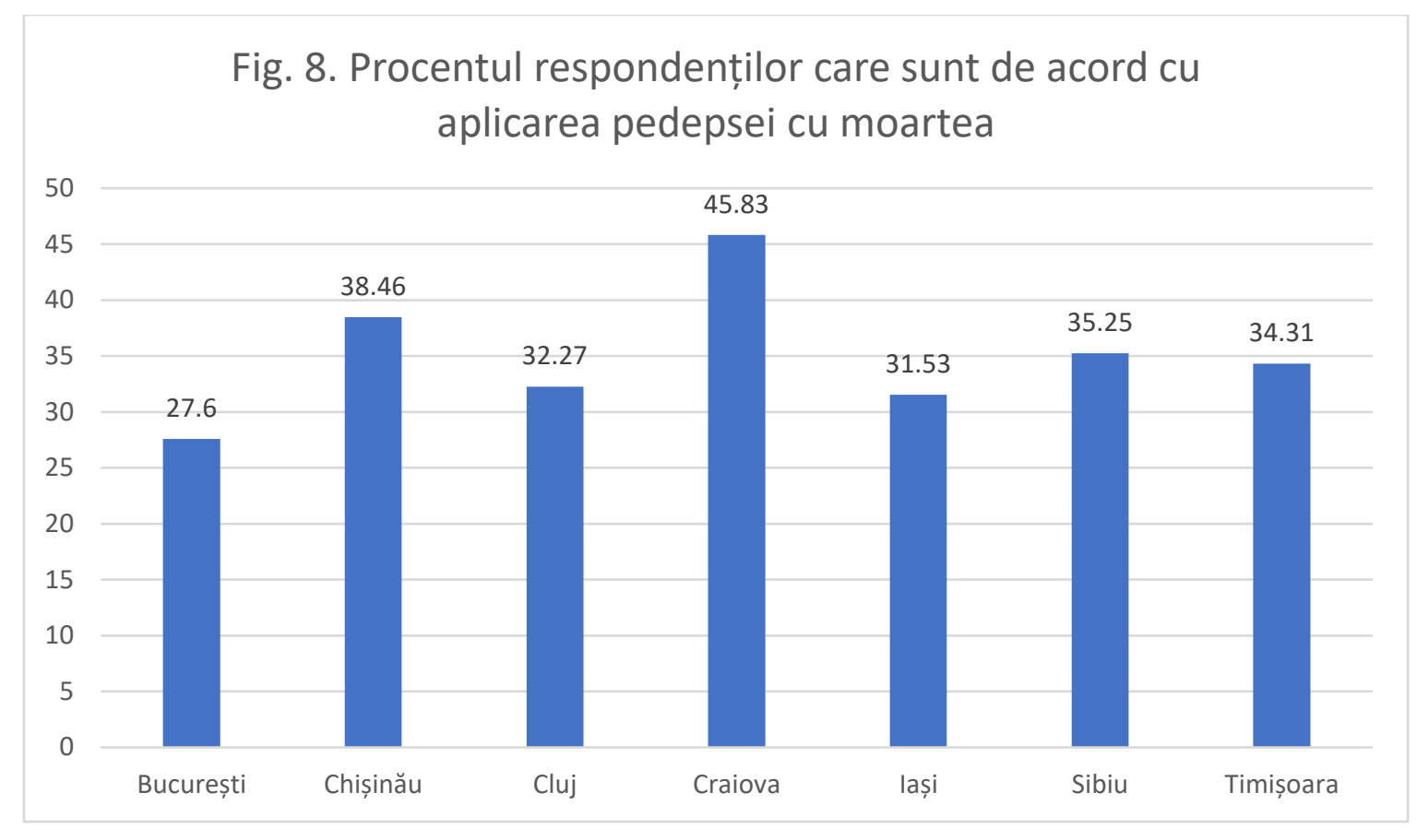

\section{1. În favoarea pedepsei cu moartea. Argumente și consecințe}

Deși a fost menționat în mai multe studii ${ }^{5}$ că, dacă participanții au alternative la pedeapsa capitală (cum ar fi pedeapsa detențiunii pe viață fără posibilitate de liberare), sprijinul pentru cea dintâi scade substanțial, sondajul nostru a plecat de la prezumția că studenții Facultăţii de Drept cunosc alternativele, care au fost enumerate doar pentru cei ce au răspuns că nu sunt de acord cu pedeapsa cu moartea. Opțiunile au fost așadar enumerate dacă studenții au ales ca răspuns că nu sunt de acord cu pedeapsa cu moartea în a doua parte a studiului, unde s-a analizat opoziţia studenților față de acest tip de pedeapsă.

Prin urmare, pentru cei 30.58\% dintre studenți (un număr de 673) care au fost în favoarea pedepsei cu moartea, chestionarul a continuat cu mai multe întrebări menite să le contureze opinia de susținere cu privire la această pedeapsă: categoriile de infracțiuni pentru care ar trebui aplicată pedeapsa cu moartea (A); justificarea aplicării pedepsei cu moartea (B), puterea de decizie în legătură cu condamnarea unei persoane la pedeapsa cu moartea (C), metodele prin care această pedeapsa ar trebui aplicată $(\mathbf{D})$, vârsta minimă și vârsta maximă pentru aplicarea pedepsei cu moartea (E) și opinia studenților despre ieșirea României din Uniunea Europeană în contextul introducerii pedepsei cu moartea în Codul penal (F).

În cadrul fiecărei întrebări, vom expune rezultatele, pentru a continua apoi cu comentariul celor constatate.

\footnotetext{
${ }^{5}$ Dick J. Hessing, Jan W. de Keijser, and Henk Elffers, Explaining Capital Punishment Support in an Abolitionist Country: The Case of the Netherlands, in Law and Human Behavior, vol. 27, no. 6, December 2003.
} 


\section{A. Categoriile de infracțiuni pentru care ar trebui aplicată pedeapsa cu moartea}

Constatări. Prima întrebare se referă la opinia studenților cu privire la ce categorii de infracțiuni ar trebui pedepsite cu pedeapsa cu moartea. Aceștia au putut alege între mai multe tipuri de infracțiuni, cu posibilitatea unor alegeri multiple: orice tip de omor, omor calificat comis asupra mai multor persoane ori de către o persoană care a mai săvârșit anterior o infracțiune de omor sau o tentativă la infracțiunea de omor, omor calificat asupra unei femei gravide, omor calificat comis prin cruzimi, viol, viol asupra unui minor, infracţiuni împotriva securităţii naționale (de exemplu, trădare, spionaj), infracțiuni de genocid, împotriva umanităţii și războiului, terorism sau niciuna dintre cele de mai sus. Dacă participanţii au dorit să adauge alte infracţiuni pe această listă, au putut face acest lucru răspunzând la următoarea întrebare: „Pe lângă infracțiunile de mai sus, considerați că pedeapsa cu moartea ar trebui aplicată (și) pentru alte fapte penale? Dacă da, menționați care:". Aproximativ 60 de studenți au răspuns și la această întrebare, adăugând alte câteva infracțiuni pe listă, pe care le vom dezvolta în secțiunea de discuții. Subliniem că nu am dorit să indicăm articole din Codul penal, pentru a da posibilitatea inclusiv studenților care nu au studiat încă partea specială a dreptului penal să răspundă la această întrebare.

După cum se poate observa în figura 9 de mai jos, categoriile care se referă la crime de genocid, împotriva umanității și războiului și terorism au fost cel mai des alese de studenţi pentru a arăta în ce cazuri ar fi de acord cu aplicarea pedepsei cu moartea. Astfel, 514 studenţi au considerat că pedeapsa cu moartea ar trebui aplicată pentru infracțiunile de genocid, iar 512 pentru infracțiunile de terorism. Având în vedere că un număr de 673 de persoane au răspuns că sunt de acord cu aplicarea pedepsei cu moartea, procentul acestor categorii de infracțiuni alese este destul de ridicat: $76.37 \%$, respectiv $76.08 \%$. În ordine, următoarea infracțiune pentru care pedeapsa cu moartea a fost considerată necesară este omorul calificat săvârșit prin cruzimi, 496 de studenţi răspunzând în acest sens (adică 73.70\%). 408 de studenţi au considerat că pentru omor calificat săvârșit asupra mai multor persoane sau de către o persoană care a mai comis anterior o infracțiune de omor sau o tentativă la infracțiunea de omor, această pedeapsă trebuie aplicată (adică 60.62\%). Trecând la alte tipuri de infracțiuni, 372 de studenți au considerat că violul asupra unui minor ar trebui pedepsit cu moartea (adică 55.27\%), în timp ce 231 (adică $34.32 \%$ ) au considerat că violul fără circumstanțe agravante trebuie pedepsit cu moartea. Doar 120 de studenți (adică 17.83\%) au considerat că pedeapsa cu moartea ar trebui aplicată persoanelor care comit infracțiuni împotriva securității naționale, iar susținerea cea mai scăzută în acest sens a avut-o infracțiunea de omor (113 studenți, adică 16.79\%). 
Fig. 9. Categorii de infracțiuni pentru care ar trebui aplicată pedeapsa cu moartea

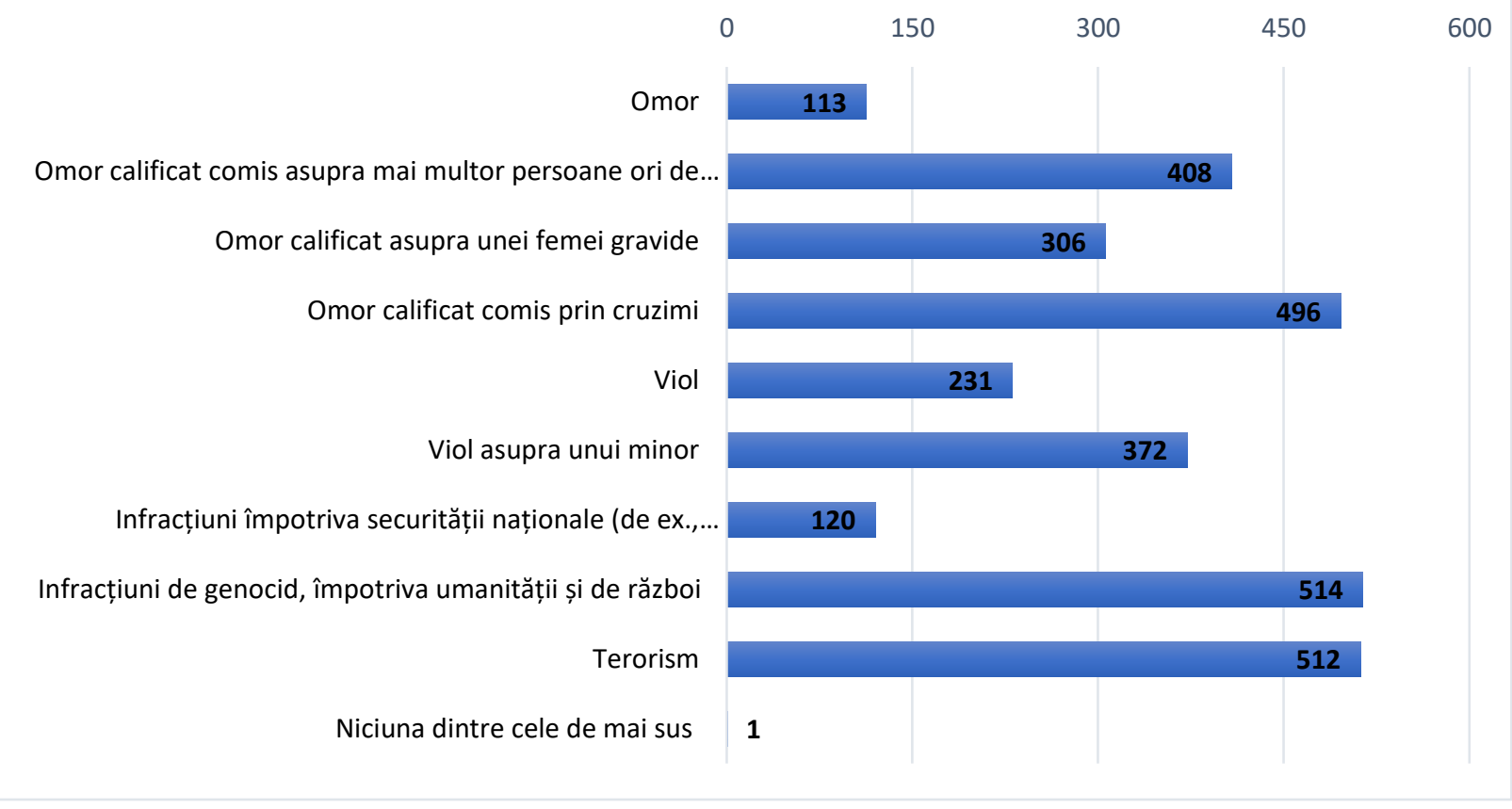

Discuție. Numărul foarte mare de răspunsuri în favoarea aplicării pedepsei cu moartea pentru infracțiunile de genocid nu este surprinzător (fiind una dintre cele mai grave infracțiuni din toate sistemele juridice care o prevăd ca atare, pedepsită și de Codul penal român cu detențiune pe viață, în caz de război aceasta fiind și unica pedeapsă prevăzută de lege). De asemenea, numărul studenților care au considerat că infracțiunile de terorism ar trebui pedepsite în acest mod nu este neașteptat, deoarece grupările teroriste au asaltat aproape întreaga Europă în ultimii ani ${ }^{6}$.

$\mathrm{Cu}$ toate acestea, o discuție mai amplă merită făcută în lumina altor infracțiuni mai des întâlnite în practica judiciară inclusiv în România, cum ar fi omorul și violul. Studenții respondenți consideră că omorul calificat săvârșit prin cruzimi este o infracțiune care ar trebui pedepsită cu moartea în viziunea studenților, împreună cu omorul calificat săvârșit asupra mai multor persoane sau de către o persoană care a mai comis anterior o infracțiune de omor sau o tentativă la infracțiunea de omor, dar de asemenea, omorul calificat asupra unei femei gravide. Accentul pare a fi pus pe periculozitatea infractorului, care stârnește un sentiment de teroare în rândul publicului prin comiterea unui omor prin cruzime (incendiere, tăierea membrelor în timp ce persoana este încă în viață, lovituri repetate cu diferite obiecte sau tăieturi multiple de cuțit, pentru a chinui victima suplimentar înainte de a o omorî etc.) sau care își dovedește periculozitatea fie prin numărul de victime, fie prin faptul că a mai comis o infracțiune de omor

\footnotetext{
${ }^{6}$ De altfel, pedeapsa cu moartea pentru infracțiunile de terorism este un subiect intens discutat și în plan internațional. Pentru argumente în favoarea pedepsei cu moartea pentru astfel de infracțiuni, a se vedea Thomas M. McDonnell, The Death Penalty--An Obstacle to the "War on Terrorism"?, 37 Vand. J. Transnat'l L. 353 (2004), p. 389, http://digitalcommons.pace.edu/lawfaculty/279
} 
după ce săvârșise deja o astfel de faptă sau chiar prin vulnerabilitatea victimei, care este însărcinată.

În afara acestor aspecte, ceea ce este foarte interesant este că omorul, comis fără nicio altă circumstanță agravantă sau alt element circumstanțial agravant, care ar trebui pedepsit cu moartea în viziunea participanților este mai puțin grav din această perspectivă decât violul și violul asupra unui minor. Un motiv pentru această perspectivă poate fi cazul care a șocat întreaga țară în luna iulie 2019, când un bărbat a fost acuzat că a violat în mod repetat două minore, pe care ulterior le-a ucis și le-a ars cadavrele. În urma acestei tragedii, au fost propuse modificări la Codul penal pentru creșterea pedepselor pentru viol și s-a prevăzut în Codul penal imprescriptibilitatea răspunderii penale pentru această infracțiune și pentru cea de act sexual cu un minor $^{7}$, dar au existat, de asemenea, numeroase petiții online pentru reintroducerea pedepsei cu moartea pentru infracțiunile de viol și infracțiunile comise de infractori care nu mai pot fi reintegrați în societate (una dintre petiții cu peste 180.000 de semnături) ${ }^{8}$.

Un sondaj efectuat la București în anul 1996, care a arătat că 59.5\% persoane erau în favoarea pedepsei cu moartea a concluzionat că ,mai mult de $80 \%$ dintre persoanele care consideră criminalitatea ca fiind $\hat{\imath}$ creștere în cartierele lor susțin o revenire la pedeapsa capitală. Percepția siguranței cartierului are un efect negativ. In cartierele în care locuitorii se simt în siguranță, există mai puțin sprijin pentru revenirea pedepsei cu moartea"9. Dacă aplicăm prin analogie același raționament la cazul descris mai sus, este ușor de înţeles de ce și studenții la Drept ar fi de acord cu reintroducerea pedepsei cu moartea. Dacă astfel de infracțiuni pot fi comise în plină zi, fără ca organele statului să intervină în mod prompt pentru a le împiedica, oamenii se simt în pericol și consideră că singura opțiune rămasă valabilă este ca persoanele respective să fie pedepsite cu moartea.

Trebuie precizat totodată că mai mult de jumătate dintre studenții din anul I (cu vârste cuprinse între 19 și 20 de ani) au fost de acord că pedeapsa cu moartea ar trebui aplicată celor care au comis violuri. La polul opus se află doctoranzii (cu vârste cuprinse între 26 și 35 de ani), care, deși au răspuns într-un număr mai mic la chestionar, au considerat că nu este necesară reintroducerea pedepsei cu moartea și doar o singură persoană că ar trebui aplicată (și printre crimele alese, violul nu a fost enumerat). Numărul mare de studenţi care au ales violul printre infracțiunile care ar trebui pedepsite cu moartea se poate explica și prin aceea că un procent mare de respondenți a fost constituit din persoane de sex veminin

După cum a fost menționat anterior, au existat studenți care au adăugat alte infracțiuni la această listă, într-o secțiune separată. Aceștia au considerat că pedeapsa capitală ar trebui aplicată și pentru mai multe infracțiuni care au ca persoană vătămată un minor: infracțiunea de rele tratamente aplicate minorului sau pentru uciderea nou născutului de către mamă, pentru corupția sexuală a minorilor, racolarea minorilor în scopuri sexuale, proxenetism sau pentru pedofilie. Așa cum arătam, faptele comise asupra minorilor au condus deja la modificări ale

\footnotetext{
${ }^{7}$ Acestea s-au și materializat prin intermediul Legii nr. 217/2020 (M.Of nr. 1012 din 30 octombrie 2020)

${ }^{8} \mathrm{~A}$ se vedea https://www.petitieonline.com/semneaza_pentru_reintroducerea_pedepsei_cu_moartea.

${ }^{9}$ A se vedea Keil, Th., Gennaro, V., Andreescu, V., Perceptions of Neighborhood Safety and Support for the Reintroduction of Capital Punishment in Romania: Results From a București Survey, în International Journal of Offender Therapy and Comparative Criminology, 43(4), 1999, p. 518
} 
Codului penal, prin Legea nr. 217/2020, iar alte modificări sunt în prezent $\operatorname{adoptate}^{10}$ ori încă discutate ${ }^{11}$.

Alte infracțiuni pentru care unii studenţi au menționat că ar trebui aplicată pedeapsa cu moartea sunt: pentru tortură, pentru infracțiuni împotriva sănătății publice (inclusiv infracțiunea de prevenire a bolilor, pentru care un student a considerat de fapt că pedeapsa cu moartea ar trebui aplicată celor care nu respectă măsurile impuse în timpul stării de urgență cauzate de pandemia CoVid-19), infracțiuni împotriva animalelor, infracțiuni împotriva funcționarilor publici, poliție, magistrați, avocați, corupție (pentru aceștia din urmă, 7 studenți dintre cei aproximativ 60 de persoane care au ales să adauge alte infracțiuni la listă). Deși corupția nu este o infracțiune violentă și nu afectează sănătatea mentală sau fizică a unui minor (așa cum a fost în cazul celorlalte opțiuni ale studenților), includerea ei în lista infracţiunilor pentru care ar trebui aplicată pedeapsa cu moartea poate fi o consecință a faptului că România este încă considerată o țară cu un grad ridicat de corupție, iar sentimentul general este că sistemul politic este corupt ${ }^{12}$. Pornind de la această opțiune care ia în calcul pedeapsa capitală pentru infracțiuni de corupție, este interesant să subliniem că, cel puțin în opinia unor studenți, pedeapsa cu moartea nu este neapărat un răspuns la comiterea unei infracțiuni violente.

\section{B. Justificarea aplicării pedepsei cu moartea}

Constatări. În continuare, studenții au fost întrebați: „Considerați că pedeapsa cu moartea în situațiile de mai sus este justificată pentru că....". Studenții au putut alege între cinci motive pentru susţinerea pedepsei capitale, cu posibilitatea unor alegeri multiple și au răspuns după cum urmează (și cum poate fi observat și în figura 10 de mai jos): „este cel mai eficient mod de prevenire a săvârșirii unor altor infracțiuni” (325 de studenți, adică 48.29\%), ,este un modalitate justă de retribuție pentru victimă și / sau familia sa” (niciun student), „este foarte costisitor pentru stat şi pentru societate să întrețină o persoană în închisoare toată viaţa" (313 studenți, adică 46.51\%), „dacă o persoană este condamnată la inchisoare pe viață și există posibilitatea eliberării condiționate, persoana respectivă ar putea săvârși și alte infracțiuni" (451 studenți, adică 67.01\%), ,este just ca o persoană care a ucis o altă persoană ori care a săvârşit infracţiuni de o gravitate deosebită să-şi piardă dreptul la viaţă" (212 studenţi, adică $31.5 \%$ ) și „,niciuna dintre cele de mai sus” (23 de studenţi, adică 3.42\%).

La fel ca în cazul întrebării anterioare, dacă studenții au dorit să extindă motivele pentru care au fost de acord cu pedeapsa cu moartea, au putut răspunde la următoarea întrebare: „Pe lângă motivele de mai sus, există (și) alte motive pentru care considerați pedeapsa cu moartea ca fiind justificată? Dacă da, menționați care: ". Aproximativ 90 de studenți au adăugat alte

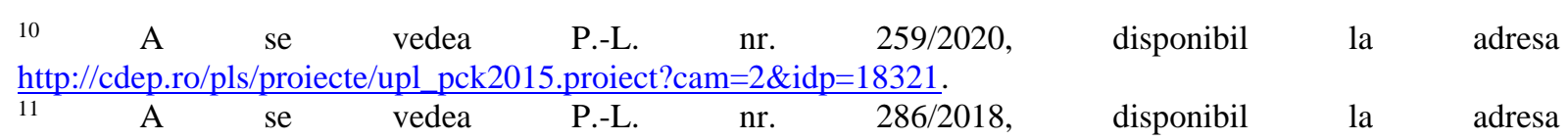
http://cdep.ro/pls/proiecte/upl_pck2015.proiect?cam=2\&idp=16526 (Curtea Constituțională a declarat legea adoptată neconstituțională, din motive însă ce nu vizează fondul modificărilor propuse).

${ }^{12}$ Conform Transparency International, ultimul indice de percepție a corupției în România a fost de 44/100, cu mult sub media la nivelul Uniunii Europene de 64/100. Pentru mai multe detalii în legătură cu acest subiect, a se vedea: https://www.transparency.org.ro/ro/tiropage/indicele-de-perceptie-coruptiei-2019. 
câteva motive pentru susținerea pedepsei capitale, pe care le vom dezvolta în secțiunea următoare.

\section{Fig. 10. Justificarea aplicării pedepsei cu moartea}

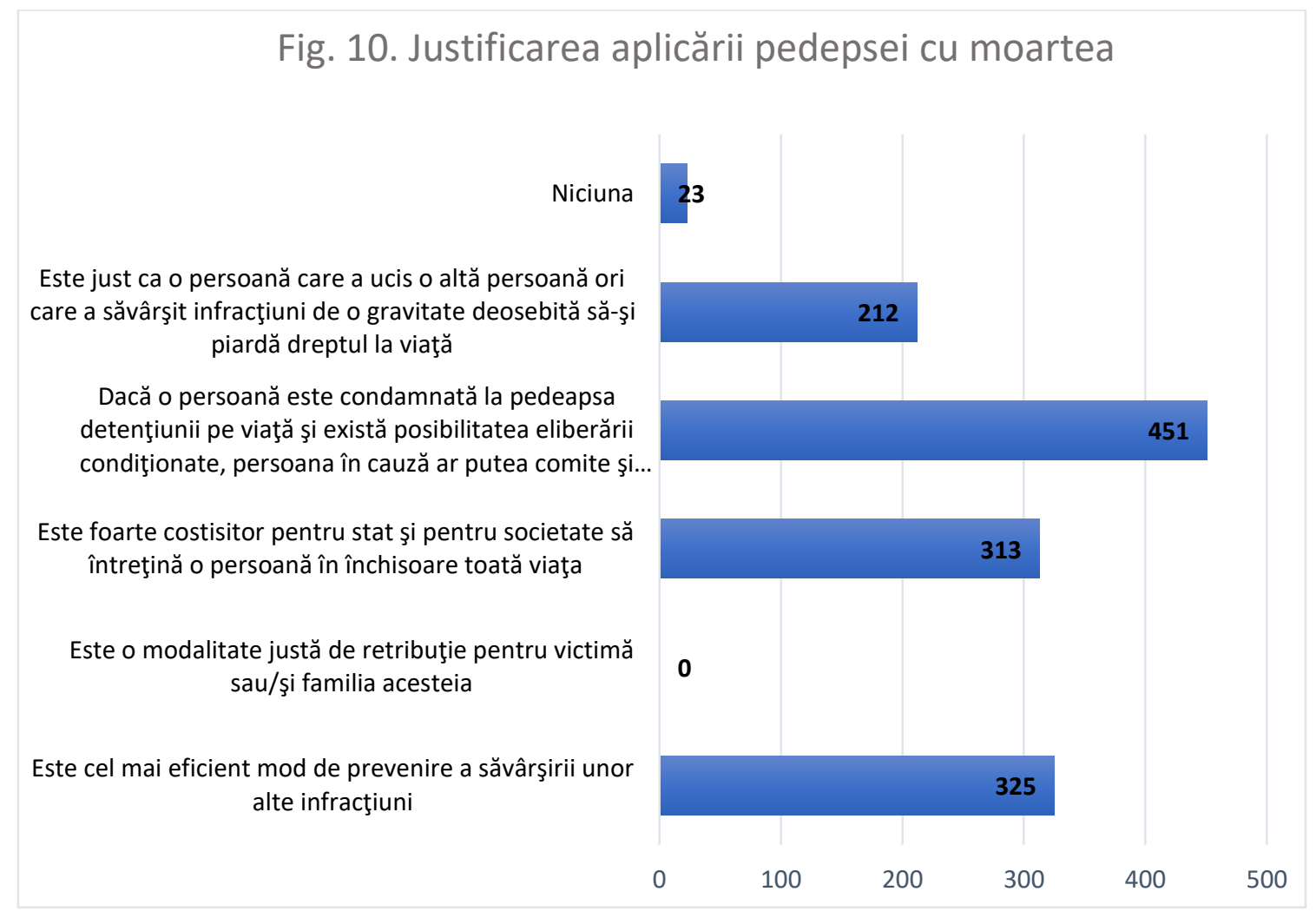

Discuții. Cei mai mulți studenți, 451 (adică 67\%), au considerat că, dacă o persoană este condamnată la pedeapsa detențiunii pe viață și există posibilitatea eliberării condiţionate, persoana în cauză ar putea comite și alte infracțiuni. $\mathrm{Cu}$ alte cuvinte, studenții se arată neîncrezători în posibilitatea ca încarcerarea unei persoane pentru o perioadă determinată să poată aduce o schimbare în conduita sa viitoare.

După cum menționam, 325 de studenți (adică 48.20\%) au considerat că aplicarea pedepsei cu moartea este cel mai eficient mod de prevenire a altor infracțiuni. Acest motiv pentru susținerea pedepsei cu moartea a fost pus în strânsă legătură cu ,,argumentul descurajării" ${ }^{13}$, în sensul că oamenii se simt descurajaţi să comită mai multe infracțiuni dacă ştiu că pot fi condamnați la moarte. Dar, aşa cum a menţionat Cesare Beccaria încă din secolul al XIX-lea, infractorii nu sunt atât de descurajaţi de intensitatea pedepsei, ci de durata acesteia, „pentru că sensibilitatea noastră este mai ușor și durabilă mişcată de minute, dar de impresii repetate decât de un șoc trecător" ${ }^{14}$. Mai mult, ceea ce are un efect mai descurajant chiar decât durata pedepsei este certitudinea aplicării acesteia, după cum arată tot Beccaria: „nu cruzimea pedepselor frânează cel mai bine infracțiunile, ci infabilibilitatea lor (...) Certitudinea unei

\footnotetext{
${ }^{13}$ A se vedea G. Moens, A. Keith Thompson, Perspective constituționale, filosofice și istorice privind dezbaterea pedepsei capitale in Australia și Statele Unite ale Americii, disponibil la: http://www.ugb.ro/Juridica/Issue2RO/5_Capital_punishmentMoens.RO.pdf

${ }^{14}$ C. Beccaria, On crimes and punishments, Cambridge Texts in the History of Political Thought, 1995, p. 67.
} 
pedepse, chiar dacă moderată, va provoca întotdeauna o impresie mai puternică decât teama de o pedeapsă mai aspră însoțită de speranța impunității, căci un rău, fie el minim dar sigur, sperie întotdeauna sufletele omenești, în timp ce speranța, acel dar ceresc care adesea ne ține loc de toate, îndepărtează ideea altor rele mai grave, mai ales atunci când este însoțită de impunitate (...)" ${ }^{\prime 15}$.

În general, motivele suplimentare menționate de participanți nu au fost diferite de cele prezentate în opțiuni. Răspunsurile au repetat aceleași idei, reformulate, cum ar fi efectul descurajant al pedepsei cu moartea („Prin creșterea asprimii sancțiunilor se descurajează viitoarele infracțiuni, se crește respectul față de autorități (...), scăderea numărului de recidivă și eliminarea dintr-o societate sănătoasă a unor persoane bolnave - $\hat{\imath}$ cazul infracțiunilor enumerate anterior de cele mai multe ori infractorii suferă de tulburări psihice sau au o atitudine/percepție care nu poate fi schimbată”.), costurile ridicate pe care le implică păstrarea în închisoare pe viață a unui condamnat (,De asemenea, comparativ cu cea mai aspră pedeapsă din România, cea a detențiunii pe viață, pedeapsa cu moartea e mai potrivită din rațiuni economice. Intreținerea unor condamnați pe o perioada atât de lungă de timp este costisitoare, în condițiile în care aceștia nu pot fi obligați la muncă remunerată sau neremunerată în folosul comunității”.); cei mai mulți studenți au considerat că pedeapsa cu moartea este justificată deoarece infractorul este incorigibil (,Reeducarea unor astfel de infractori este aproape imposibilăa, criminologia însăși demonstrând acest lucru. Mai ales în cazul infracțiunilor de viol a căror victimă a fost un minor - cu precădere în cazul în care minorul avea o vârstă fragedă, până în 10 ani - această pedeapsă, în anumite condiții foarte bine delimitate de lege, ar trebui să fie o posibilitate oferită judecătorului care stabilește pedeapsa inculpatului." sau „Nu cred că persoanele inculpate se mai pot reintegra în societate. Consider că, dacă ar fi eliberate, în proporție de $90 \%$ ar recidiva".). După cum se poate observa, această incorigibilitate nu este altceva decât reiterarea faptului că cei condamnați la detențiunea pe viaţă ar fi ,predispuși” la comiterea altor infracțiuni, dacă ar fi liberați. Din analiza alegerilor pe care studenții le-au realizat, a răspunsurilor predefinite, dar și a celor adăugate de către ei înșiși ulterior, rezultă faptul că majoritatea sunt de acord cu aplicarea pedepsei cu moartea pentru că sistemul judiciar, împreună cu cel penitenciar, nu oferă suficiente garanții că o persoană condamnată pentru o infracțiune gravă ar mai putea fi reintegrată social după executarea pedepsei (prin ajungerea la termen sau prin liberare condiţionată).

Această idee este susținută și prin raportare la un alt eveniment recent din România, și anume cazul unui bărbat care fusese condamnat la detențiunea pe viață pentru săvârșirea a cinci infracțiuni de omor, începând executarea pedepsei din anul 1993. În luna mai a anului trecut, el a fost eliberat condiționat, după executarea a 26 de ani de închisoare, iar, un an mai târziu, a fost acuzat din nou de tentativă la infracțiunea de omor, constând în aceea că a dat foc unei tinere de 17 ani, aceasta suferind arsuri pe 90\% din suprafaţa corpului. Acest caz a creat un

\footnotetext{
${ }^{15}$ A se vedea C. Beccaria, Despre infracțiuni și pedepse, Ed. Humanitas, București, 2007, p. 169.
} 
sentiment public de revoltă în rândul populației ${ }^{16}$, stârnind discuții majore despre eficacitatea închisorii și a pus la îndoială posibilitatea liberării condiționate în astfel de cazuri grave ${ }^{17}$.

\section{Puterea de decizie în legătură cu condamnarea unei persoane la pedeapsa cu moartea}

Constatări. Având în vedere că, în diferite state, puterea decizională pentru aplicarea pedepsei cu moartea aparține unor diferite categorii de persoane, această întrebare a avut drept scop aflarea opiniei studenților cu privire la care ar fi cea mai potrivită persoană pentru a decide aplicarea acestei pedepse, cu consecința directă a schimbării Codului de procedură penală din România pentru a permite ca sentința la pedeapsa cu moartea să fie pronunțată și de alte entități. După cum sugerează titlul, întrebarea era formulată astfel: „Cine credeți că ar trebui să aibă puterea de a decide condamnarea unei persoane la moarte? (puteți alege mai multe răspunsuri)". Aceștia au putut alege între: judecător (singur sau într-un complet de judecători), Curtea cu jurați (sau orice alt tip de grup de persoane din afara sistemului judiciar), șeful statului (indiferent de calitatea sa: președinte, monarh etc.).

Deoarece opțiunile oferite în întrebarea anterioară erau limitate, următoarea întrebare le-a permis studenților să își exprime opinia cu privire la cine ar trebui să ia decizia cu privire la aplicarea pedepsei cu moartea, în următoarea formulare: „Dacă considerați că (și) alte persoane / entități ar trebui să ia decizia cu privire la aplicarea pedepsei cu moartea, să menționeze cine / în ce condiții: ". Aproximativ 80 de persoane și-au exprimat, de asemenea, opinia cu privire la această întrebare, pe care o vom dezvolta în secțiunea despre discuţii.

După cum se poate vedea în figura de mai jos (figura 11), majoritatea studenților, 458 (adică 68.05\%), au considerat că judecătorul ar trebui să fie cel care decide (singur sau într-un complet de judecători), urmat de 278 de studenți (adică 41.31\%) care au considerat că o instanţă cu juriu (ca în S.U.A.) este cea care poate decide. 90 de studenți (adică 13.37\%) cred că șeful statului ar trebui să aplice această pedeapsă, un procent destul de mare dacă avem în vedere faptul că studenții la Drept cunosc deja modalitatea de funcționare a sistemului judiciar și atribuțiile fiecărei autorități publice, iar 43 (adică 6.39\%) nu sunt de acord cu niciuna dintre cele trei opțiuni propuse.

\footnotetext{
${ }^{16}$ A se vedea https://www.digi24.ro/stiri/actualitate/justitie/de-ce-a-fost-eliberat-criminalul-care-a-dat-foc-uneitinere-de-17-ani-are-o-atitudine-corecta-fata-de-regulile-de-convietuire-sociala-1322808

17 Încrederea populaţiei în posibilitatea reintegrării sociale în astfel de cazuri a fost şi mai mult afectată de faptul că Judecătoria îi respinsese cererea de liberare condiționată, considerând că, deși primise câteva recompense, "s- $a$ preocupat pentru a se evidenția în mod constant abia începând cu anul 2014, astfel că s-a apreciat că recompensele acordate până în acest moment nu fac dovadă unei adevărate îndreptări a condamnatului, ci reprezintă un simulacru pentru obținerea mai grabnică a liberării condiționate". A se vedea, Jud. Drobeta Turnu Severin, s.pen. nr. 1350/2017, www.rolii.ro. Decizia a fost contestată de inculpat, iar Tribunalul i-a admis cererea, dispunând prin decizie definitivă liberarea condiționată a acestuia, apreciind că ,perioada executată a fost suficientă pentru reeducarea condamnatului T.I. și că acesta, prin participarea activă la programele desfășurate în vederea pregătirii graduale pentru liberare și-a format și consolidat o atitudine corectă față de valorile sociale, față de ordinea de drept și față de regulile de conviețuire socială, funcțiile de exemplaritate și eliminare temporară ale pedepsei fiind îndeplinite în cazul său”. A se vedea Tribunalul Mehedinți, dec. nr. 502/2017, www.rolii.ro.
} 


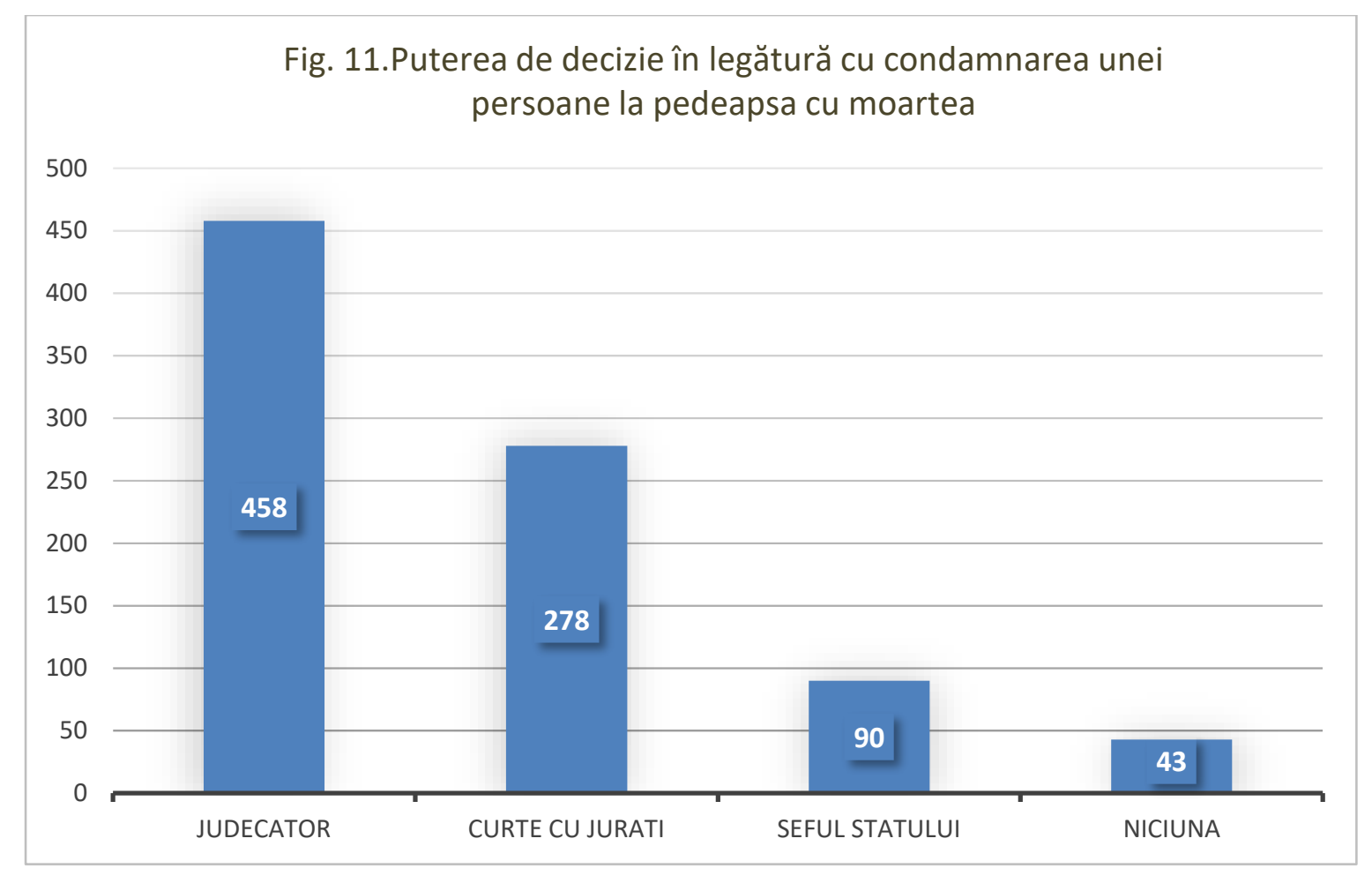

Discuții. După cum s-a menționat mai sus, studenții și-au putut exprima opinia cu privire la persoana care ar trebui să decidă aplicarea pedepsei cu moartea, având în vedere că opțiunile anterioare au fost prezentate neexhaustiv. Deși nu au avut răspunsuri predefinite, cei aproape 80 de studenți care au răspuns la această întrebare au dat răspunsuri similare, care pot fi împărţite în următoarele categorii:

Un complet de judecători. O mare parte din cei care au adăugat alte opțiuni aici au dorit doar să sublinieze că, deși au ales ,judecătorul (singur sau într-un complet de judecători)", sau referit doar la un complet de judecată care ar trebui să fie compus dintr-un număr care a variat de la 2 la 5 judecători) și în niciun caz doar un judecător. Au fost alţi studenți care au menționat că judecătorii care compun completul ar trebui să fie doar de la Înalta Curte de Casație și Justiție: „completul de minim 5 judecători de la Înalta Curte, cu avizul (imperativ) al șefului de stat" (chiar dacă competența de a judeca unele dintre infracțiunile menționate mai sus ar putea aparține chiar judecătoriilor - pentru viol, de exemplu).

Prin aceste răspunsuri, se pare că studenții acceptă că ar putea apărea erori judiciare, dar consideră că ar putea fi prevenite prin decizia mai multor judecători. În același timp, numărul foarte mare de răspunsuri în favoarea judecătorilor poate fi datorat și faptului că participanţii sunt studenți la Drept.

Membri ai societății civile, psihologi, psihiatri. Alți studenți au dorit să adauge că membrii societății civile, psihologii, psihiatrii care ar fi mai în măsură să înțeleagă ce se întâmplă în mintea unui criminal ar trebui să intre în acest grup, chiar dacă nu fac parte din sistemul judiciar: „O curte cu jurați care sa fie din afara sistemului judiciar, dar care sa dețină anumite calități si care sa fie aleși in prealabil (o curte cu jurați formată din oameni din mai multe domenii si care fac parte din mai multe paturi sociale)". Aceste răspunsuri sunt în directă legătură și cu cele de la întrebarea anterioară, care au pus accentul pe faptul că persoanele care 
comit astfel de infracțiuni grave suferă de tulburări psihice care ar conduce, de cele mai multe ori, la imposibilitatea reintegrării sociale și a înțelegerii consecințelor faptelor comise.

Procurorul. În plus, unii dintre participanți au considerat că procurorul ar trebui să ia parte și el la decizie, deoarece acesta a fost cel care a strâns și a administrat toate probele sau majoritatea acestora. În mod evident, o astfel de soluție este aleasă de studenții din anii mai mici, care nu au studiat încă noțiunea de ,magistrat” în cadrul dreptului procesual penal ori în lumina prevederilor Curții europene a drepturilor omului.

Victima sau membrii victimei familiei. Alte răspunsuri au vizat chiar victima sau membrii familiei ei, ca persoane care ar fi cel mai bine poziţionate să decidă aplicarea pedepsei cu moartea.

Poporul (prin referendum). La fel ca în cazul răspunsului amintit la lit. d), și prin această opțiune, studenții consideră că alegerea pedepsei cu moartea trebuie să fie una pur afectivă, fie pentru răzbunare (în cazul victimei sau a membrilor familiei acesteia, ceea ce amintește de Legea talionului), fie din considerente ce țin de afectarea societății în ansamblul său (ceea ce, de altfel, stă la baza includerii dreptului penal în categoria mai largă a dreptului public în România).

Varietatea răspunsurilor adăugate la această întrebare denotă și faptul că, deși într-o proporție mai mică, studenții consideră că ar fi nevoie de schimbări majore la nivelul sistemului judiciar, de vreme ce, în prezent, nicio altă autoritate a statului în afara judecătorului nu este implicată în aplicarea unei pedepse. Totodată, interesant de observat este faptul că acești studenți consideră că pedeapsa cu moartea ar trebui să aibă un regim special, diferit de cel al pedepsei cu închisoarea sau cu amenda, față de caracterul ireversibil al acesteia, dar și faptul că fie au o încredere mai mare pentru alegerea acestei pedepse în persoane care nu au legătură cu sistemul judiciar, fie, deși admit că ar putea fi aplicată de judecător, subliniază faptul că acesta ar trebui să facă parte dintr-un complet de judecată format din cel puţin doi judecători.

\section{Metodele prin care acest tip de pedeapsă ar trebui aplicată}

Constatări. Metodele de execuție nu au constituit, cu mici excepțiii ${ }^{18}$, variabile luate în calcul în studiile privitoare la percepția publică asupra pedepsei cu moartea ${ }^{19}$. Însă poziția participanților față de acest aspect poate oferi un criteriu suplimentar în funcție de care să fie înțeles procentul susținătorilor pedepsei cu moartea.

În acest chestionar, întrebarea a fost „Considerați că pedeapsa cu moartea ar trebui să fie executată prin intermediul următoarelor metode (puteți alege mai multe răspunsuri)", iar

\footnotetext{
18 Spre exemplu, într-o lucrarea lui H. Erskine, The Polls: Capital Punishment, publicată în Public Opinion Quarterly, Volumul 34, nr. 2, 1970, p. 290-307, este citat un sondaj din anul 1953 realizat în SUA, unde a fost analizată opinia publică în privința metodelor de execuție a pedepsei cu moartea, nefiind însă trecută injecția letală printre variante (p. 306).

${ }^{19}$ Situația ar putea fi explicată prin larga răspândire a injecției letale ca metodă de execuție. În diverse studii sunt analizate mai degrabă alte criterii care pot influența percepția asupra pedepsei cu moartea, cum ar fi minoritatea făptuitorilor sau convingerile religioase ale participanților la studiu (Francis T. Cullen, Bonnie S. Fisher and Brandon K. Applegate, Public Opinion about Punishment and Corrections, în Crime and Justice, Vol. 27, 2000, p. 1-79), educația, statutul social și convingerile etice ale participanților (James Midgley, Public Opinion and The Death Penalty in South Africa, în The British Journal of Criminology, Volumul 14, nr. 4, 1974, p. 345-358), etc.
} 
participanții au putut alege (după cum rezultă din întrebare) una sau mai multe dintre următoarele metode de execuție: împușcare, scaun electric, spânzurătoare și injecție letală. Distinct de variantele prezentate, a existat și varianta „niciuna”. Alături de această întrebare, pentru a nu limita răspunsurile la variantele chestionarului, a mai fost adăugată întrebarea , $\hat{I n}$ cazul în care considerați că pedeapsa cu moartea ar trebui să fie executată (și) prin alte metode, specificați care sunt acestea".

Majoritatea participanților (557, adică $82.76 \%$ ) s-a poziționat în favoarea injecției letale, iar motivul unei astfel de poziționări rezultă, așa cum vom vedea la secțiunea de Discuții, din completările pe care o mare parte dintre aceștia le-au făcut prin răspunsurile la întrebarea suplimentară. Totodată, 137 de studenți (adică 20.36\%) au considerat că împușcarea este o metodă potrivită de execuție, 111 (adică 16.49\%) au fost în favoarea scaunului electric, 64 (adică 9.51\%) pentru spânzurătoare, iar 19 participanți (adică 2.82\%) au considerat că niciuna dintre metodele prezentate nu sunt potrivite. Aceste numere pot fi observate în diagrama de mai jos.(Figura 12)

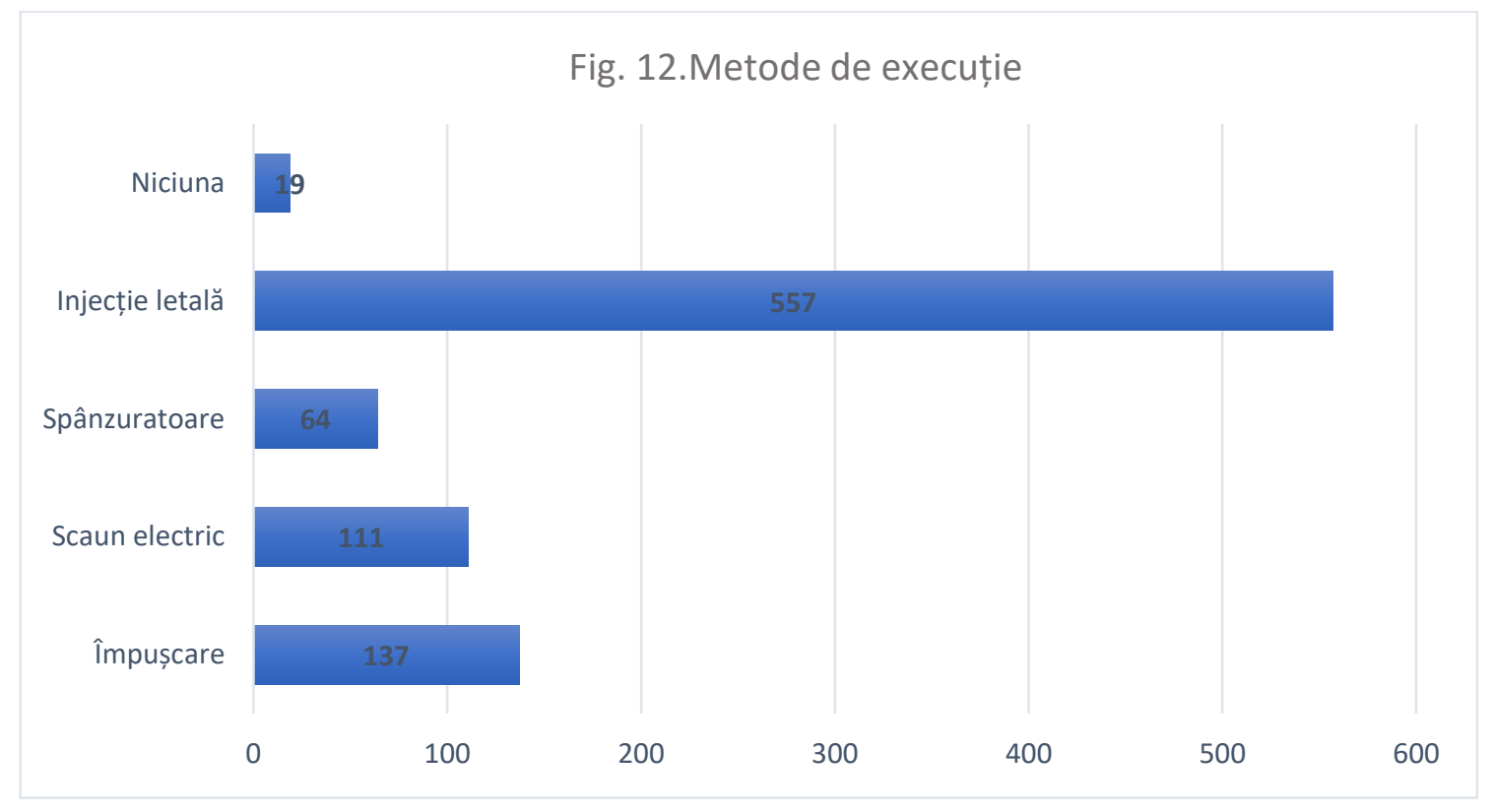

Discuții. Poziționarea majorității participanților în favoarea injecției letale este explicabilă prin statutul acesteia de cea mai răspândită metodă de execuţie la ora actuală ${ }^{20}$. Deși a apărut ca o variantă mai ieftină de execuţie a pedepsei capitale, injecția letală a ajuns, totodată, să fie considerată cea mai puțin chinuitoare pentru condamnat. Însă, odată cu popularizarea metodei s-a dezvoltat și fenomenul de „medicalizare” a execuției întrucât procesul de injectare a substanței letale presupune asistență medicală de specialitate. Chiar și în aceste condiții, în literatura de specialitate există numeroase poziții care susțin că statutul actual al injecției letale nu este susținut de dovezi științifice solide, în principal din lipsa unor studii care să ofere

\footnotetext{
${ }^{20} \mathrm{https}: / /$ deathpenaltyinfo.org/executions/methods-of-execution
} 
suficiente informații cu privire la caracteristica metodei de a preveni „durerile și vătămările suplimentare" 21 .

Dincolo de controverse, injecția letală este în mod larg cunoscută ca o metodă ,umană” de execuție, ceea ce se reflectă, așa cum rezultă și din acest studiu, în preferințele publicului în materie de modalități ale execuţiei pedepsei cu moartea. Pentru că proporția de $82.76 \%$, susținătoare injecției letale, poate fi o reflecție în percepția publică atât a răspândirii acestei modalităţi de execuție, cât și a popularizării sale drept o metodă care asigură o moarte mai blândă. În corelație cu acest procent, au existat răspunsuri suplimentare (completate în cadrul întrebării la care participanții puteau răspunde cu alte metode distincte de cele standard oferite în chestionar) prin care a fost exprimată această idee. Astfel, 16 participanţi au considerat că metodele nu sunt importante dacă cel condamnat nu simte durere.

Corelația poate fi observată din următoarele constatări: pe de-o parte, în cadrul primei întrebări majoritatea participanților au preferat o metodă de execuţie care în percepția publică este considerată blândă; pe de altă parte, în cadrul celei de-a doua întrebări, ideea necesității unei metode de execuție care să nu provoace dureri condamnatului a strâns în jurul ei cele mai multe răspunsuri de susținere (restul răspunsurilor oferite la cea de-a doua întrebare a fost, aşa cum vom vedea în continuare, distinct din punctul de vedere al conţinutului, fără un numitor comun). Se poate presupune, deci, o preocupare a unei majorități dintre participanții susținători ai pedepsei cu moartea pentru blândețea metodei de execuţie.

În legătură cu procentele aferente celorlalte metode, doar susţinerea scaunului electric poate fi explicată prin răspândirea sa în rândul metodelor de execuție din ultimii 50 de ani. Conform unor statistici ${ }^{22}$, moartea prin electrocutare este a doua cea mai răspândită metodă de execuţie după injecția letală în S.U.A. Însă susţinerea relativ mare pentru execuţia prin împușcare nu urmează aceeași paradigmă. Totuși, execuția prin împușcare este încă o practică frecventă în alte state, precum China, Indonezia, Coreea de Nord, Arabia Saudită, Yemen etc. Aceleași aprecieri pot fi fãcute și în cazul execuției prin spânzurare.

În sfârșit, în cadrul celei de-a doua întrebări, 4 participanți au considerat că metoda ar trebui să fie aleasă de condamnat, 2 participanți au considerat că metoda ar trebui să fie aceeași cu cea utilizată la comiterea infracțiunii, iar 2 participanţi au considerat că aplicarea pedepsei cu moartea ar trebui să se facă în public. Au existat, de asemenea, răspunsuri susținând moartea dureroasă, decapitarea, somniferele, otrăvirea, înghețul, ghilotina, trasul în țeapă, plutonul de execuție, inhalarea monoxidului de carbon etc., însă acestea au fost marginale (câte 1 răspuns pentru fiecare dintre aceste variante).

\section{E. Vârsta minimă și vârsta maximă a condamnatului la moarte}

Constatări. Având în vedere că minorii pot fi pedepsiți penal, în general, dar și în România, iar unele state permit aplicarea pedepsei cu moartea inclusiv pentru ei, această întrebare s-a referit la opinia studenților la drept în această privinţă.

\footnotetext{
${ }^{21}$ A se vedea o prezentare succintă a probemei în Sean Philpott, Execution by Lethal Injection: Illegal Research?, în The Hastings Center Report, Vol. 44, nr. 2, 2014, p. 11.

${ }^{22}$ A se vedea https://deathpenaltyinfo.org/executions/methods-of-execution
} 
Vârsta minimă. După cum se poate observa în figura de mai jos (Figura 13), un număr deloc neglijabil de persoane (81, adică $12,04 \%$, studenți din toți anii de studiu care sunt în favoarea pedepsei cu moartea) au considerat că pedeapsa capitală ar trebui aplicată fără a lua în considerare o vârstă minimă.

Aproape jumătate dintre studenții care sunt în favoarea pedepsei cu moartea (283, adică 42,05\%) sunt de acord, totuși, că ar trebui aplicată persoanelor cu vârsta peste 18 ani (care este și vârsta majoratului în România). Vârsta majoratului în Statele Unite ale Americii (21 de ani) a fost considerată de 120 de studenți (adică 17,83\%) adecvată ca vârsta minimă pentru aplicarea pedepsei cu moartea. Apoi, vârsta minimă de 25 de ani a fost considerată adecvată de 55 de participanţi (adică 8,17\%), în timp ce 49 (adică 7,28\%) şi, respectiv, 48 (adică 7,13\%) au ales vârsta minimă de 16 și respectiv 30 de ani. Doar 17 studenți ( adică 2,53\%) au considerat că vârsta minimă ar trebui să fie de 14 ani, iar 11 (adică 1,63\%) vârsta de 40 de ani. Doar 3, respectiv 2 studenți, au considerat că vârsta minimă ar putea fi de 50 și respectiv 60 de ani.

Fig. 13.Vârsta minimă pentru aplicarea pedepsei cu moartea

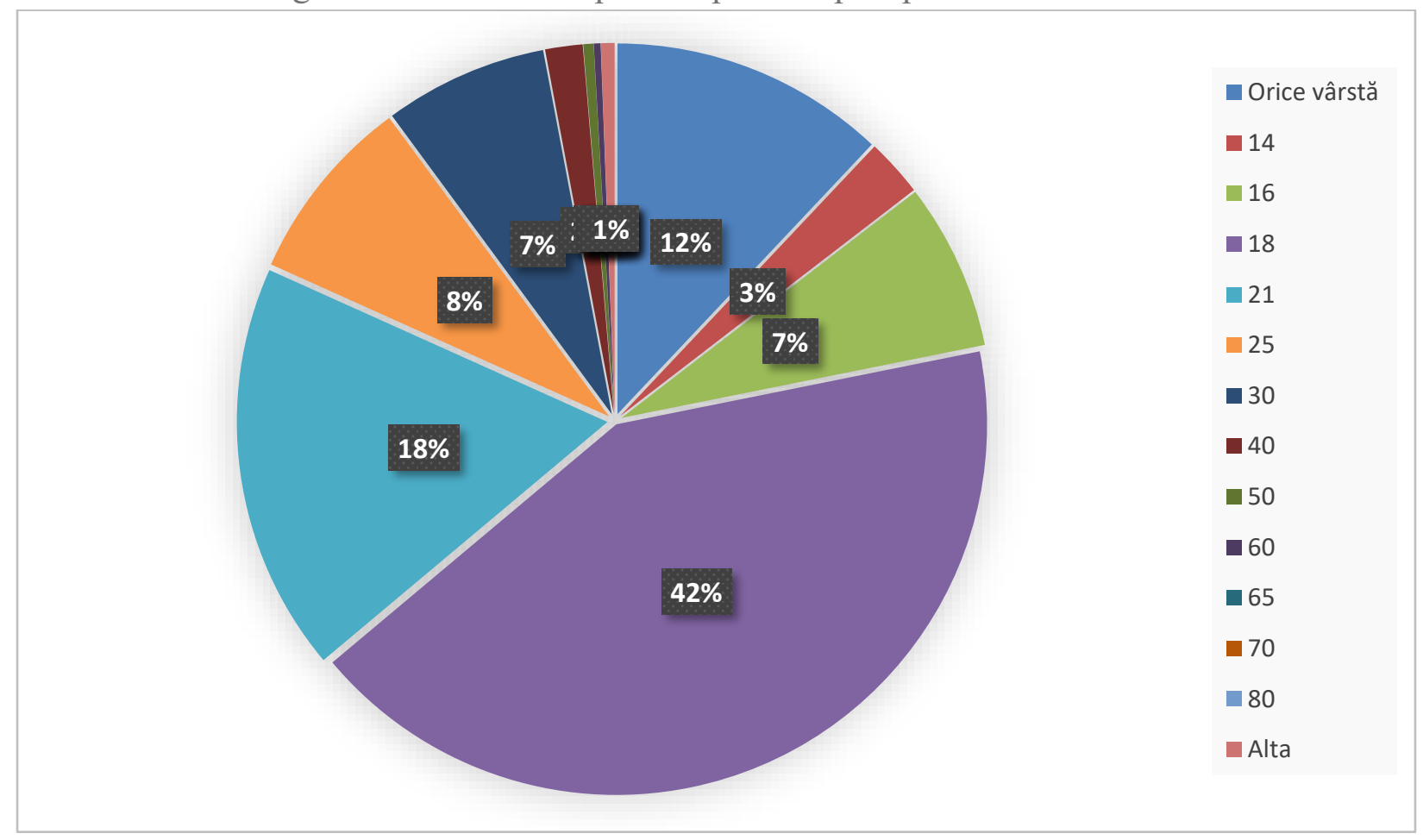

Vârsta maximă. După cum vedem în figura de mai jos (figura 14), aproximativ o treime dintre participanți $(205$, adică 30,46\%) au considerat că nu există o limită de vârstă maximă peste care pedeapsa cu moartea să nu mai fie aplicată. O a doua treime (208, adică 30,91\%) sunt de părere că vârsta maximă ar trebui să fie de 80 de ani. Cu toate acestea, pentru 1 persoană (adică 0,15\%), vârsta de 16 ani a fost considerată maximă, pentru 12 persoane, vârsta de 18 ani (adică 1,78\%), iar pentru 2, vârsta de 21 de ani (adică 0,30\%). Ceilalţi studenţi au ales vârsta de 50 de ani (60, adică 8,92\%), 60 de ani (36, adică 5,35\%), 65 de ani (9, adică 1,34\%) și 70 de ani $(53$, adică $7,88 \%)$. 
Deși Codul penal român prevede că după 65 de ani, inculpatul nu mai poate fi condamnat la detențiune pe viață, ci doar la pedeapsa închisorii, observăm că studenții care au fost de acord cu pedeapsa cu moartea susțin cu o majoritate copleșitoare $(61,37 \%)$ că făptuitorul ar trebui să fie condamnat la moarte după această vârstă, chiar și până la 80 de ani.

Fig. 14.Vârsta maximă pentru aplicarea pedepsei cu moartea

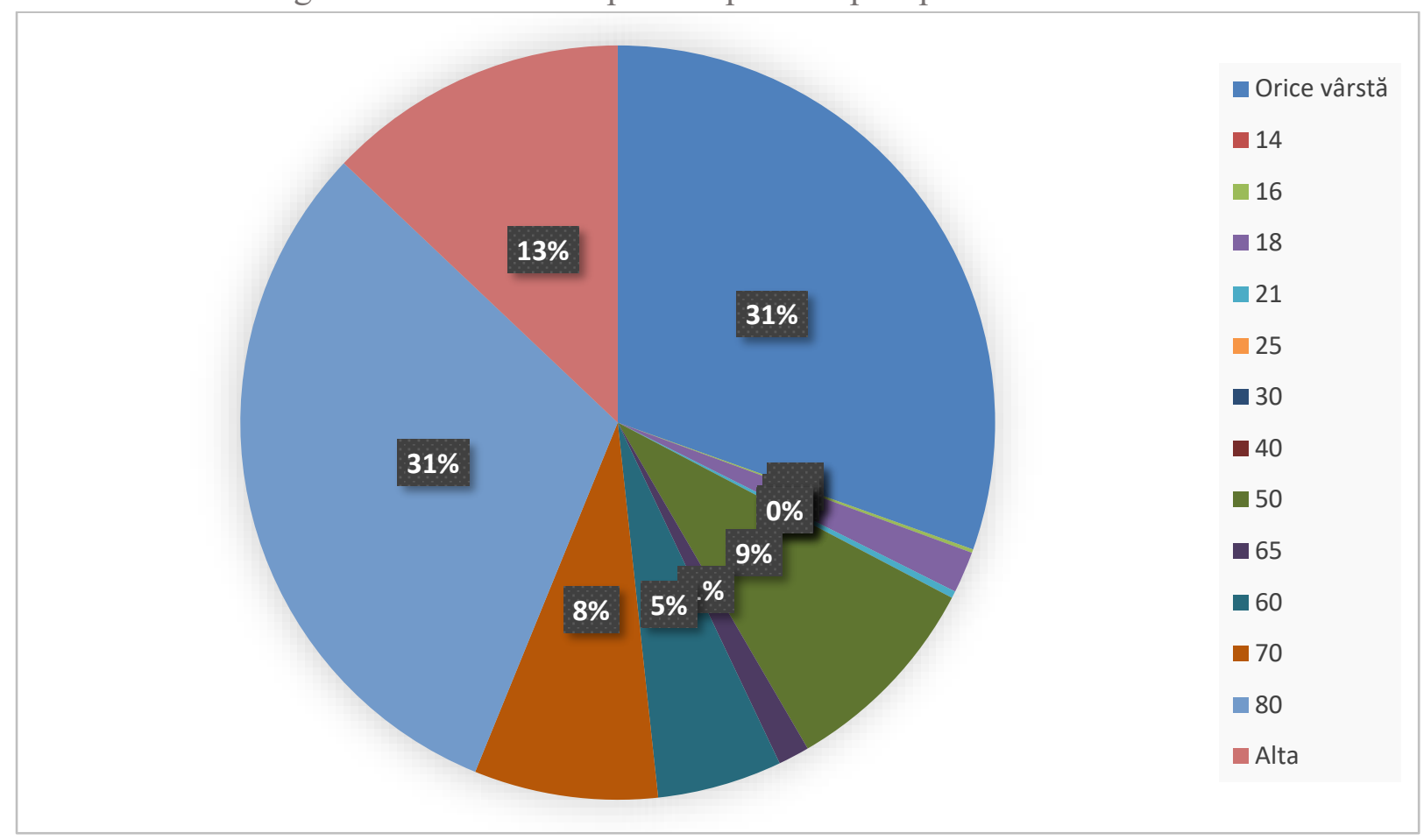

\section{Discuții}

Vârsta minimă. Legiuitorul român, la fel ca în alte state, a considerat că minorul sub 14 ani nu poate răspunde penal, fiind lipsit absolut de discernământ. În plus, din 2014, sistemul juridic românesc nu mai prevede aplicarea de pedepse minorilor, ci doar de măsuri educative, în funcție de gravitatea infracțiunii (având la bază mai multe motive: oferă șansa minorilor să se reabiliteze mai ușor, vârsta fragedă îi poate determina să nu fie pe deplin conștienți de gravitatea crimele lor etc.). Totuși, așa cum precizam, 12.05\% din studenți au considerat că nu este relevantă vârsta persoanei condamnate la pedeapsa cu moartea. O posibilă explicație ar putea fi că infracțiunile care ar trebui pedepsite cu moartea sunt atât de grave încât tinerii își pierd statutul de ,copii” și merită același tratament ca adulții. Această poziție nu este nouă și a fost prezentată și în alte studii ${ }^{23}$. Practic, și în această situație, ca și în altele pe care le aminteam în cele de mai sus, studenții acceptă faptul că pentru cazul particular al condamnării la pedeapsa cu moartea, ar trebui să se introducă o excepție cu privire la vârsta de la care se poate răspunde penal, de vreme ce legiuitorul a hotărât deja în Codul penal ${ }^{24}$ că sub vârsta de 14 ani, minorul

\footnotetext{
${ }^{23}$ A se vedea F. Cullen, B. Fisher, B. Applegate, loc. cit., p. 61. Autorii au citat alte studii care au concluzionat că $51.4 \%$ dintre persoane au fost de acord că ,tinerii de șaisprezece ani care sunt condamnați pentru crimă de gradul I merită, în general, pedeapsa cu moartea".

${ }^{24}$ Art. 113 alin. (1) C.pen.: „Minorul care nu a împlinit vârsta de 14 ani nu răspunde penal”.
} 
este prezumat în mod absolut că nu are discernământ. În plus, poziţia studenţilor poate fi datorată unor viziuni veleitare caracterului pur retributiv al pedepsei, în sensul în care comiterea celor mai grave infracțiuni nu poate fi ,reparată” decât prin moartea infractorului, singura pedeapsă aptă de a restabili dreptatea, indiferent de caracteristicile personale ale acestuia.

Proporția de $42 \%$ dintre participanți care au considerat vârsta de 18 ani drept vârstă minimă necesară pentru aplicarea pedepsei cu moartea este explicabilă prin caracteristicile sistemului juridic penal român, unde aplicarea unor pedepse se poate realiza doar față de persoanele care la data comiterii faptei împliniseră vârsta de $18 \mathrm{ani}^{25}$. De asemenea, proporția de $18 \%$ în favoarea vârstei minime de 21 de ani se poate explica din rațiuni ce țin de maturitatea celor care comit fapte de o gravitate sporită, vârsta de 18 ani putând fi considerată prea mică. Totodată, influența sistemului american, unde există încă reglementată și pedeapsa cu moartea, poate fi, de asemenea, o explicaţie.

Vârsta maximă. În privința acestui aspect proporțiile sunt echilibrate între varianta vârstei maxime de 80 de ani (31\%) și varianta inexistenței unei vârste maxime (31\%). Aceste procente sunt explicabile printr-o viziune egalitară (absolută, în cazul celei de-a doua variante sau atenuată, în cazul celei dintâi) a participanților, conform căreia o vârstă mai înaintată nu ar trebui să excludă automat persoanele de la aplicarea pedepsei cu moartea. Acesta pare a fi și motivul pentru care majoritatea participanților nu au ținut cont de vârsta de 65 de ani până la care poate fi aplicată pedeapsa detențiunii pe viață în dreptul penal român.

Însă nu poate fi ignorată nici vârsta participanților, mai ales datorită faptului că aceștia sunt în majoritate tineri sub 25 de ani. În studii relativ recente au fost descoperite corelații între vârsta persoanelor intervievate și raportarea acestora la necesitatea existenței pedepsei cu moartea, în sensul că persoanele tinere par a fi mai predispuse să susțină pedeapsa capitală ${ }^{26}$. Acest trend poate influența, în opinia noastră, inclusiv raportarea la anumite aspecte secundare în legătură cu pedeapsa cu moartea, precum vârsta de la/până la care ar trebui aplicată.

\section{F. Opinia studenților despre ieșirea României din Uniunea Europeană în contextul introducerii pedepsei cu moartea în Codul penal}

Constatări. Este bine cunoscut faptul că aderarea la Uniunea Europeană necesită, printre alte condiții, inclusiv abolirea pedepsei cu moartea, iar reintroducerea acestei pedepse este incompatibilă cu calitatea de stat membru al Uniunii. Iar prin întrebarea „Dacă, pentru a putea introduce în Codul penal pedeapsa cu moartea, România ar trebui să iasă din Uniunea Europeană, ați fi de acord cu acest lucru" poate fi măsurat, într-un anumit sens, nivelul real de susținere a pedepsei cu moartea. Reintroducerea pedepsei capitale nu reprezintă doar o problemă socială și etică, ci şi una cu consecințe politice imediate. E posibil ca o persoană care susține principial pedeapsa cu moartea să-și modifice optica atunci când este pus în fața unor consecințe importante pe care reintroducerea acestei pedepse le poate avea. În fond, odată

\footnotetext{
${ }^{25}$ Art. 114 alin. (1) C.pen. prevede cu titlu de regulă: „Față de minorul care, la data săvârşirii infracțiunii, avea vârsta cuprinsă între 14 și 18 ani se ia o măsură educativă neprivativă de libertate”.

${ }^{26}$ D. J. Hessing, J. W. de Keijser, H. Elffers, Explaining Capital Punishment Support in an Abolitionist

Country: The Case of the Netherlands, în Law and Human Behavior, Vol. 27, No. 6, December 2003, p. 619.
} 
depășite convingerile intime cu privire la subiecte sociale sensibile (precum acesta), participantul este pus în fața unei alegeri de tip utilitarist. Din acest punct de vedere, întrebarea ar putea fi reformulată în termenii următori: Este pedeapsa cu moartea cu adevărat necesară pentru societatea românească astfel încât să justifice ieșirea din Uniunea Europeană?

Totodată, conform Eurobarometrului din Noiembrie $2019^{27}$ (publicat bianual de către Comisia Europeană), România nu se află printre țările cu populație eurosceptică, ci, dimpotrivă, conform procentelor publicate în studiul Comisiei, este pe locul al doilea în topul statelor membre cu un nivel ridicat de încredere în privința direcției înspre care se îndreaptă Uniunea Europeană (după Irlanda și înaintea Croației). Mai mult de jumătate din populația României consideră că Uniunea se îndreaptă într-o direcție corectă (52\%), ceea ce reprezintă un procent mult peste media europeană $(31 \%)$. Acest optimism de care populaţia României dă dovadă poate fi luat în considerare la interpretarea rezultatelor chestionarului în privinţa acestei întrebări, fiind de aşteptat ca majoritatea celor care s-au poziţionat pentru reintroducerea pedepsei cu moartea să nu dorească ieșirea României din Uniune în acest scop.

Așa cum se poate observa în figura de mai jos (figura 15), 30\% dintre participanți au considerat că România ar trebuie să părăsească Uniunea Europeană pentru a reintroduce pedeapsa cu moartea, iar $70 \%$ dintre aceștia nu au fost de acord cu o astfel de soluție ${ }^{28}$.

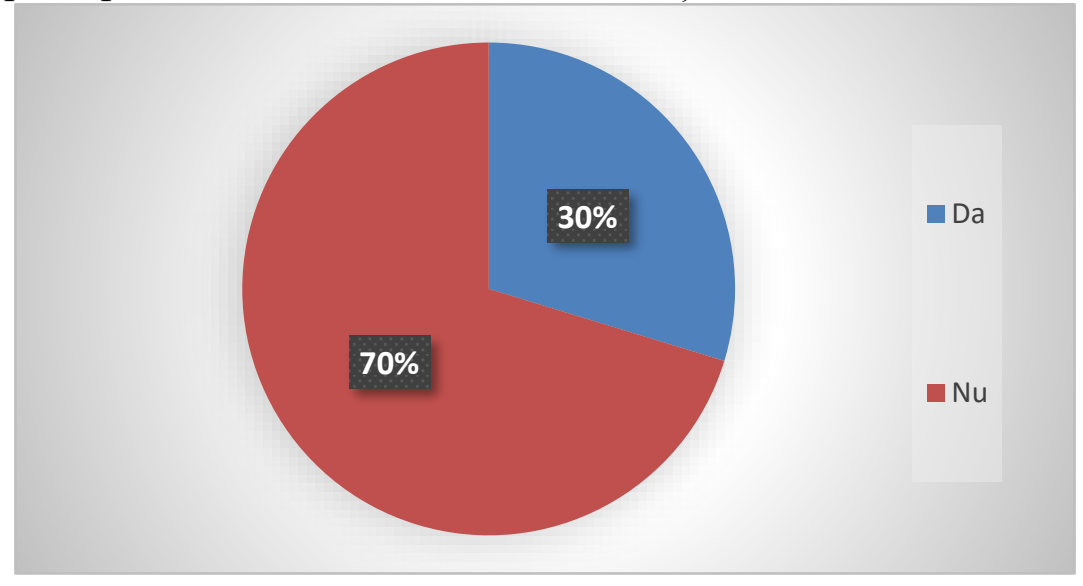

Fig. 15. Opinia studenților despre ieșirea României din Uniunea Europeană în contextul introducerii pedepsei cu moartea în Codul penal

Analizând răspunsurile în funcție de celelalte variabile, am constatat că dintre participanții care au fost de acord cu reintroducerea pedepsei cu moartea (așa cum rezultă din Figura 16): în cazul studenților în anul I (132) 32 au răspuns „Da” la această întrebare (19 femei și 13 bărbați); în cazul studenților de anul II (201) 51 au răspuns „Da” la întrebare (33 femei și 18 bărbați); în cazul studenților de anul III (166) 55 au răspuns „Da” la întrebare (37 femei și 18 bărbați); în cazul studenților de anul IV (128) 47 au răspuns „Da” la întrebare (32 femei și 15 bărbați); în cazul studenților de la Master (45) 15 au răspuns „Da” la întrebare (10 femei și

\footnotetext{
${ }^{27}$ Eurobarometrul poate fi consultat aici. Ne-am referit la Eurobarometrul din Noiembrie 2019, iar nu la cel mai recent din Octombrie 2020, întrucât primul se situează în perioada imediat anterioară desfășurării activităților de culegere a datelor pentru prezentul studiu (ceea ce îl face mai relevant).

${ }^{28}$ Cifrele sunt consistente și cu cele obținute în rândul studenților provenind de la alte facultăți din cadrul Universității din București, $36 \%$ din cei 46 de respondenți declarându-se în favoarea părăsirii Uniunii Europene într-o astfel de situaţie.
} 
5 bărbați); în cazul studenților de la Doctorat (16) doar 1 singur student a fost de acord cu pedeapsa cu moartea, însă nu a răspuns „Da” la această întrebare.

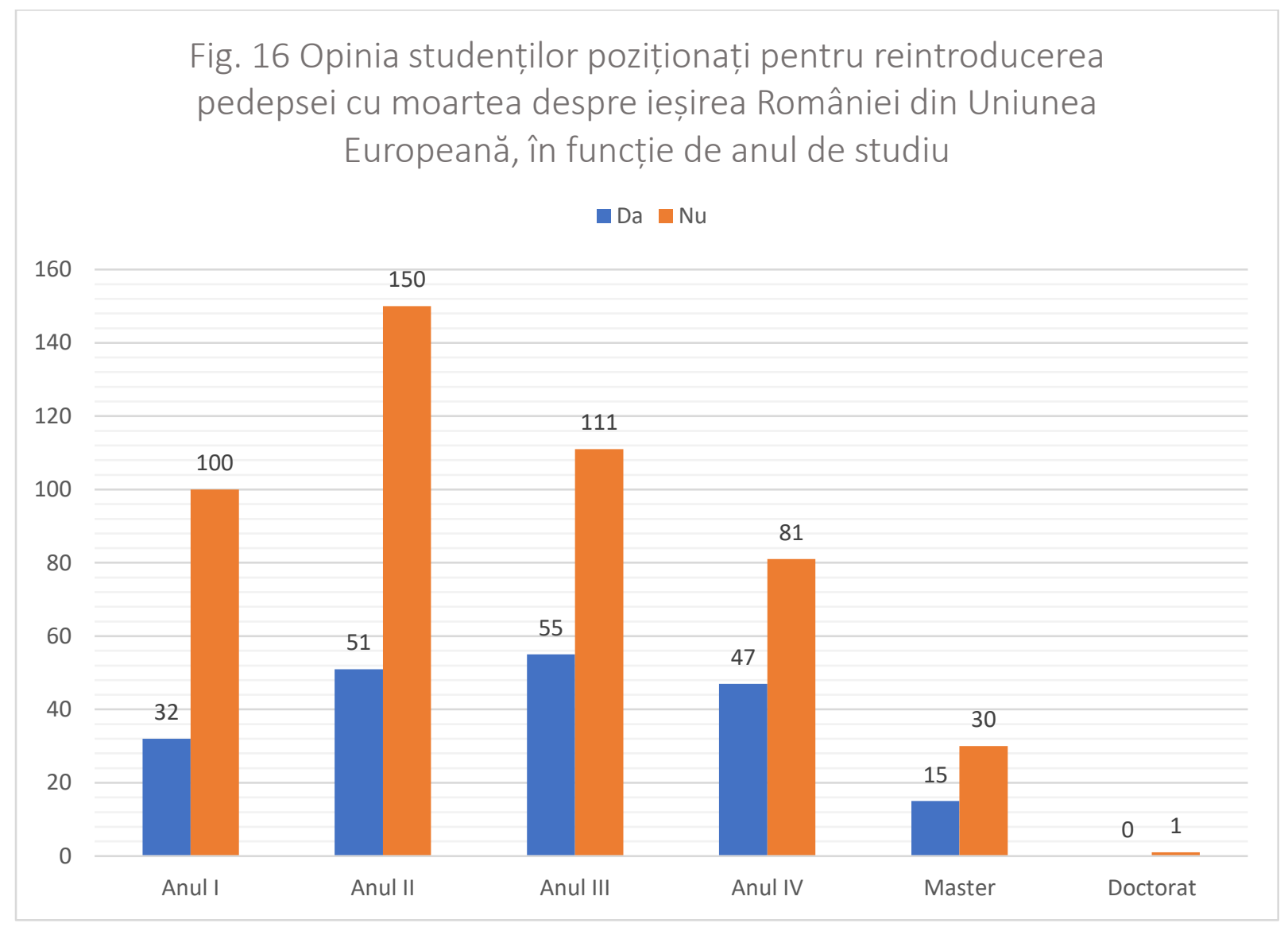

Unele dintre aceste variabile nu prezintă o relevanță deosebită. Spre exemplu, raportul dintre participanții de sex feminin și masculin este irelevant deoarece numărul de femei care au răspuns la acest chestionar a fost mai mare, pentru motivele expuse în prima parte a studiului. Însă ponderea răspunsurilor în funcție de anul de studiu poate prezenta importanță pentru formularea unor concluzii.

Discuții. Așa cum anticipam anterior, această întrebare a pus participanții în faţa unei alegeri între a își menține poziţia cu privire la necesitatea reintroducerii pedepsei cu moartea și a renunța la această poziție în fața unei potențiale consecințe politice. Din această perspectivă, unele dintre răspunsurile participanților ar putea fi rezultatul aplicării unui filtru utilitarist fiindcă în fața unei alegeri de acest tip, întrebarea „Care dintre aceste două chestiuni aduce mai multe avantaje României?" apare inerent. Pe de altă parte, nu putem prezuma că acest filtru utilitarist a fost aplicat de fiecare dintre participanţi. În procentul de $30 \%$ dintre răspunsuri, susținător al soluției sacrificării calității României de stat membru al Uniunii, este probabil să se regăsească nu doar răspunsuri ale unor participanţi care consideră mai importantă reintroducerea pedepsei cu moartea, ci și răspunsuri ale unor participanţi eurosceptici sau cu puternice afinități în legătură cu pedeapsa cu moartea.

Există, de asemenea, posibilitatea ca unii dintre participanți să nu fi cunoscut faptul că această calitate de stat membru al Uniunii presupune imposibilitatea reintroducerii pedepsei cu 
moartea, iar, deși s-au poziționat iniţial pentru pedeapsa capitală, și-au schimbat opinia la momentul la care au fost puși în fața alegerii dintre cele două variante (reintroducerea pedepsei cu moartea cu condiția ieșirii României din Uniune sau menţinerea situației actuale). Totuși, considerăm că această variantă este puțin probabilă, luând în considerare atât calitatea participanților de studenți la Drept, cât și proporțiile dintre aceștia care au preferat varianta ieșirii României din Uniune, în funcție de anii de studiu. Astfel, cei mai mulți susținători ai acestei variante raportat la numărul total de susţinători ai pedepsei cu moartea (în funcție de fiecare an de studiu) se regăsesc în cadrul anului IV, unde dintr-un total de 128 susținători ai pedepsei capitale, 47 ar prefera ieșirea din Uniunea Europeană (aproximativ 36\%). Totodată, în cadrul anului 3 și al Masterului, au rezultat procente de aproximativ 30\%, similare cu media tuturor răspunsurilor. În schimb, în cadrul anului I, din 132 de susținători ai pedepsei capitale, doar 32 au preferat ieșirea României din Uniunea Europeană (aproximativ 24\%), iar în cadrul anului II din 201 susținători, doar 51 s-au poziţionat pentru această soluţie (aproximativ 25\%). Având în vedere că procentele sunt mai mici în cazul anilor I și II, este dificil de acceptat varianta conform căreia aceștia cunoșteau mai bine situația expusă anterior decât colegii lor din anii III, IV și Master.

Așa cum anticipam mai sus (în secțiunea de Constatări), rezultatele înregistrate de Eurobarometrul din Noiembrie 2019 se reflectă și în concluziile acestui studiu. Astfel, majoritatea studenților care s-au poziționat inițial pentru reintroducerea pedepsei cu moartea nu au considerat că această măsură ar trebui implementată cu consecința ieșirii României din Uniunea Europeană. Această concluzie este concordantă cu cea a Eurobarometrului, care a arătat că majoritatea populației României este optimistă în privinţa viitorului Uniunii.

Ca atare, considerăm că varianta potrivit căreia procentul de susținere a pedepsei cu moartea este mai mic atunci când subiecții nu aleg doar în baza preferințelor, ci și prin luarea în considerare a unor variabile suplimentare, înfățișate în acest caz prin consecințe practice pe care reintroducerea pedepsei cu moartea le-ar putea avea, este mai probabilă. Această constatare nu presupune că participanții nu cunoșteau relația dintre reintroducerea pedepsei capitale și statutul de stat membru al Uniunii Europene. Mai degrabă, la momentul poziţionării pro sau contra pedepsei cu moartea, în lipsa unor variabile oferite de chestionar, decizia imediată se realizează fără luarea în considerare a unor consecințe precum cele expuse mai sus.

\section{Contra pedepsei cu moartea. Argumente și consecințe.}

După cum am arătat în partea introductivă a prezentului studiu, un procent de 69,42 dintre respondenți s-au poziționat împotriva pedepsei cu moartea ${ }^{29}$. Așadar, cel puțin din aria studiată pe calea acestui chestionar, majoritatea susține politica penală actuală a României în acest subiect.

Totuși, similar abordării celor care sunt de acord cu pedeapsa capitală, chestionarul a urmărit să obțină perspective și asupra altor aspecte conexe împotrivirii față de această formă extremă de sancționare. În acest sens, întrebările subsecvente au abordat următoarele chestiuni: motivele poziționării împotriva pedepsei cu moartea (A), alternativele acceptate pentru

\footnotetext{
${ }^{29}$ După cum se va putea observa în cuprinsul capitolului V, acest procent este, în realitate, mai mic.
} 
pedeapsa cu moartea în cazul celor mai grave infracțiuni (B) și aplicabilitatea pedepsei cu moartea în situații excepționale (C).

În continuare, vom analiza rezultatele chestionarului într-o manieră defalcată prin raportare la fiecare dintre aspectele enumerate anterior. În cazul fiecărui subiect, analiza va fi împărțită în 3 secțiuni: aspecte introductive și relevanța întrebării, constatări statistice; și comentarii analitice.

\section{A. Motivele poziționării împotriva pedepsei cu moartea}

Dintre argumentele ce pot fi aduse împotriva pedepsei cu moartea, în mod inevitabil, unele sunt mai puternice decât altele. Unele argumente pot fi combătute în mod facil, iar altele sunt mai puțin susceptibile la replică. ${ }^{30}$ Or, în măsura în care cea mai mare parte dintre cei ce se declară împotriva pedepsei cu moartea ar avea drept fundament un argument slab, pretabil la critici, desigur, generic situația ar fi de natură să nască probleme subsecvente.

Pentru aceste motive, chestionarul nostru a urmărit să obțină și perspectivele respondenților asupra argumentelor care îi determină să fie împotriva pedepsei capitale.

Constatări statistice. Astfel cum se poate constata în figura de mai jos (figura 17), la întrebarea „Motivul sau motivele pentru care nu sunteți de acord cu aplicarea pedepsei cu moartea este/sunt", respondenții au putut alege între mai multe variante, corespunzător unei eventuale multitudini de motive pentru care sunt împotriva pedepsei capitale.

În total, 1528 de persoane au răspuns acestei întrebări, respectiv, evident, acele persoane care au răspuns „Nu” la întrebarea „Sunteți de acord cu aplicarea pedepsei cu moartea?”. Dintre aceste persoane, numai 18 au selectat varianta „Niciunul din cele de mai sus”, rezultând un procent puțin semnificativ de $1,17 \%$ respondenți care, aparent, au alte motive care îi determină să se poziționeze împotriva pedepsei cu moartea, în afara celor expuse de chestionar.

\footnotetext{
${ }^{30} \mathrm{O}$ analiză semnificativ de obiectivă a argumentelor în favoarea și împotriva pedepsei cu moartea în literatura de specialitate americană se poate observa în W. Hochkammer, The Capital Punishment Controversy, în Journal of Criminal Law and Criminology, volume 60, issue 3, 1970, pag. 360-368. De asemenea, în același sens, a se vedea R. Lantin, The Death Penalty Debate: a Look at the Main Arguments, în International Journal of Humanities and Social Science, volume 7, no. 3, 2017, pag. 43-47.
} 
Fig. 17. Motivele poziționării împotriva pedepsei cu moartea

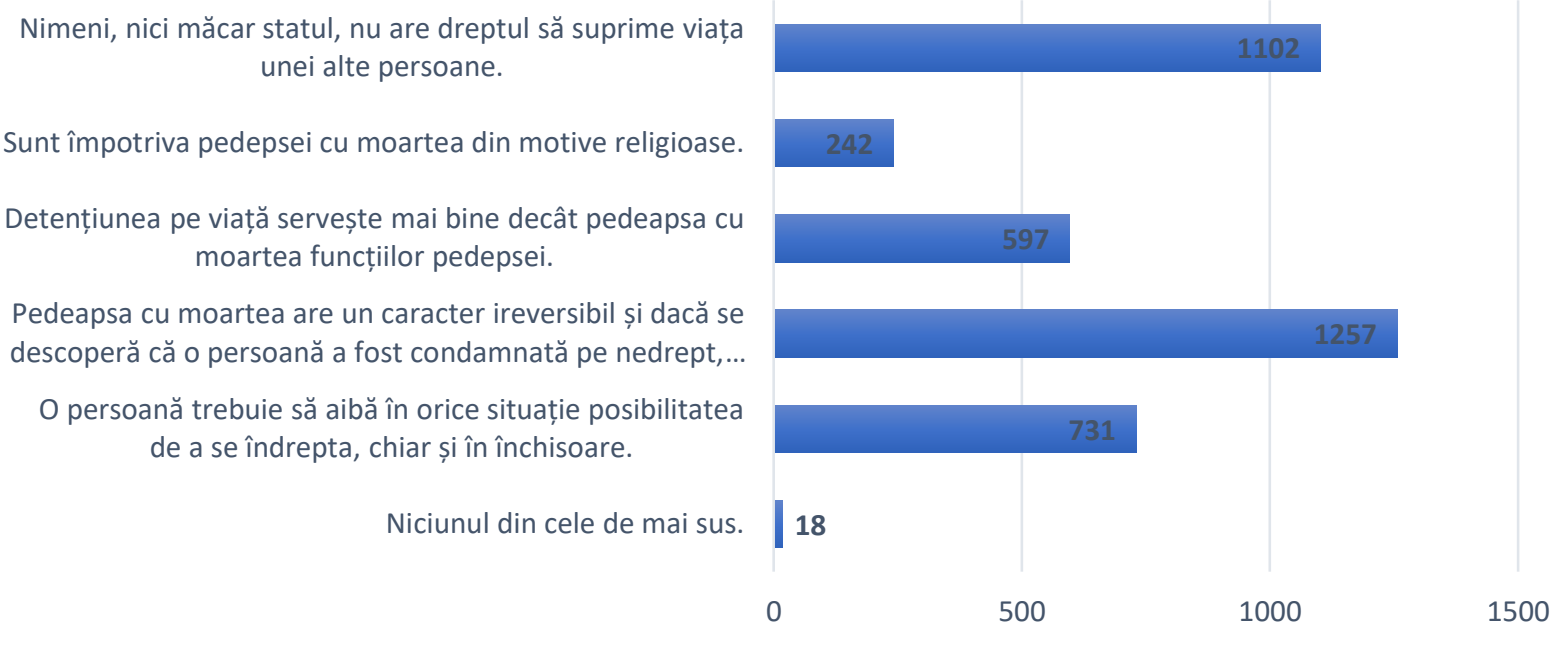

Probabil primul aspect care iese în evidență în demersul de observare a rezultatelor este reprezentat de numărul relativ mic de persoane care au indicat argumentul religios drept motiv pentru care se situează împotriva pedepsei capitale. 242 de persoane au indicat acest motiv, reprezentând $15,83 \%$ din totalul respondenților. La extrema cealaltă se află răspunsul „Pedeapsa cu moartea are un caracter ireversibil și dacă se descoperă că o persoană a fost condamnată pe nedrept, ea nu mai poate fi readusă la viață”. Astfel, argumentul posibilității existenței unor erori judiciare este important pentru 82,26\% dintre respondenţi (1257 din 1528 de persoane).

Tot un argument îmbrățișat de un procent ridicat de persoane este cel referitor la inviolabilitatea absolută a dreptului la viață (,Nimeni, nici măcar statul, nu are dreptul să suprime viața unei alte persoane"). 1102 din totalul de 1528 de respondenți au indicat acest motiv, reprezentând $72,12, \%$.

În fine, celelalte două posibile motive au fost selectate de un număr relevant de persoane, dar aflat sub jumătatea totalului respondenților. Argumentul comparativ, referitor la utilitatea sporită a detențiunii de viață prin raportare la pedeapsa capitală, a fost indicat de 39,07\% dintre respondenți (597 din 1528 de persoane). Motivul reprezentat de lipsa caracterului educativ al pedepsei cu moartea (,O persoană trebuie să aibă în orice situație posibilitatea de a se indrepta, chiar și în închisoare”) a fost selectat de 47,84\% dintre cei chestionați (731 din 1528 de persoane).

În introducerea prezentului studiu, am arătat că $51,25 \%$ dintre respondenți provin din celelalte cinci facultăţi de drept din Hexagonul Facultăţilor de Drept și de la Facultatea de Drept a Universității de Stat din Moldova. În acest context, apreciem că ar fi utilă o comparație selectivă a răspunsurilor indicate de studenții Facultății de Drept a Universităţii din București (48,75\% dintre respondenţi) cu răspunsurile indicate de ceilalţi participanți chestionați.

Astfel, așa cum se poate observa și în Figura 18 de mai jos, am constatat că argumentul de natură religioasă a fost selectat de aproape 12,5\% dintre studenții Facultății de Drept a Universității din București. În schimb, compilând răspunsurile oferite de studenții celorlalte 
şase facultăți, am constatat că 19,3\% dintre aceștia au indicat argumentul religios ca fiind relevant. Un element interesant descoperit în analiza răspunsurilor este că, dintre aceste șase facultăţi, cele în cazul cărora cel mai mare procent de respondenţi s-au declarat a fi de acord cu pedeapsa cu moartea sunt și cele în cazul cărora procentul respondenților care au indicat argumentul religios drept un motiv de opoziţie față de pedeapsa capitală este mult sub media indicată anterior. Astfel, în cazul studenților Facultății de Drept a Universității din Craiova, $45,83 \%$ au arătat că sunt de acord cu pedeapsa capitală, cel mai mare procent, prin comparație cu celelalte facultăţi de drept. Or, tocmai în cazul acestei facultăţi, procentul de studenţi care, fiind împotriva pedepsei cu moartea, au indicat argumentul religios este deosebit de mic, respectiv numai 9,23\%. Similar, în cazul studenților Facultății de Drept a Universității de Stat din Moldova (unde 38,46\% dintre respondenți s-au declarat de acord cu pedeapsa capitală), numai $12,5 \%$ dintre cei poziționați contra pedepsei cu moartea au indicat argumentul religios.

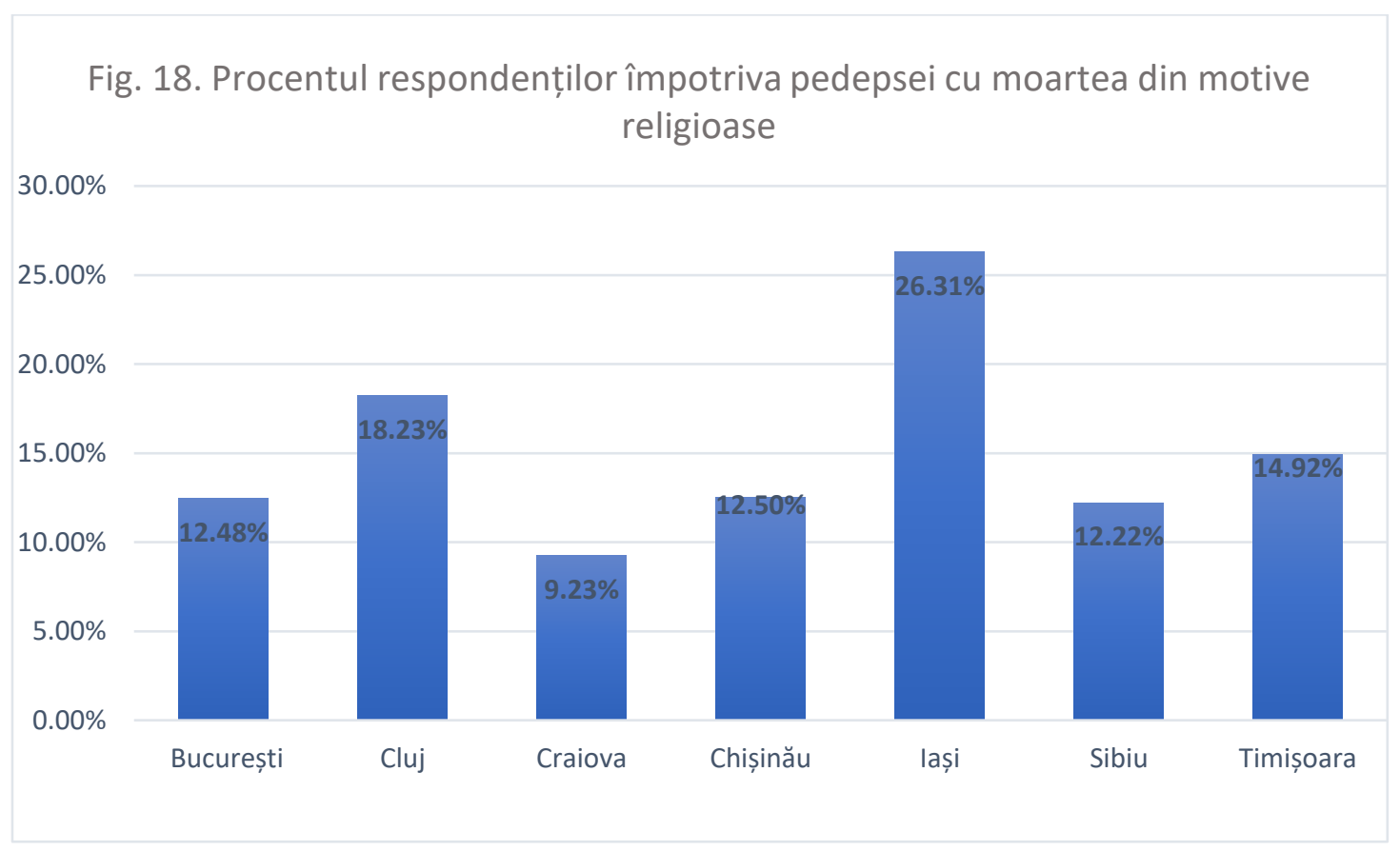

În fine, diferențe între ponderea răspunsurilor, comparând studenții Facultății de Drept a Universităţii din București cu studenții celorlalte șase facultăți, mai identificăm în cazul celor mai selectate motive. Astfel, argumentul posibilităţii existenței unor erori judiciare a fost indicat de 84,8\% dintre studenții Facultății de Drept a Universității din București și de 79,6\% dintre studenții celorlalte șase facultăţi. În fine, argumentul referitor la inviolabilitatea absolută a dreptului la viață a fost indicat de 73,4\% dintre studenții Facultăţii de Drept a Universității din București și de 70,8\% dintre studenții celorlalte șase facultăţi.

Comentarii analitice. Analiza răspunsurilor oferite de studenți la întrebarea privind motivele poziționării împotriva pedepsei cu moartea scoate în evidență mai multe aspecte interesante.

În primul rând, așa cum spuneam, observăm numărul relativ mic de respondenți care au ales drept fundament argumentul de natură religioasă. $\mathrm{Cu}$ siguranță, acesta este rezultatul unei schimbări de optică ce s-a produs de-a lungul ultimelor decenii. Putem estima oarecum 
rezonabil că un asemenea studiu, efectuat cândva la începutul secolului XX ar fi avut rezultate pronunțat diferite în ce privește acest motiv.

Totuși, probabil că ar fi o greșeală să interpretăm numărul mic de persoane care au indicat argumentul religios drept o consecință rezultată exclusiv din procesul de secularizare a societăţii. Un potențial motiv suplimentar al relativei lipse de interes pentru acest argument este reprezentat de caracterul său interpretabil, sinuos. Inclusiv în istoria dezbaterii asupra pedepsei capitale, așa cum am arătat și mai sus, raționamentele canonice, indiferent de denominațiunea religioasă din care proveneau, au fost folosite atât în susținerea acestui tip de pedeapsă, cât și împotriva sa. Așadar, o cale alternativă de interpretare a rezultatelor chestionarului este reprezentată de un efect pe care dezvoltarea societății 1-a putut avea. Anumite categorii probabil că realizează astăzi tocmai acest caracter dual al argumentului și, în consecință, evită să își fundamenteze opinia pe acesta.

În al doilea rând, observăm, poate în mod surprinzător, că un procent relativ mic au indicat argumentul privind superioritatea detențiunii pe viață, prin comparație cu pedeapsa capitală, în atingerea funcțiilor pedepsei. Dintre aceste funcții, am dori să ne concentrăm în special pe cea preventivă, poate cea mai intuitivă într-o asemenea discuție. ${ }^{31}$ Constatăm, pe cale de interpretare, că numai o minoritate dintre opozanții pedepsei cu moartea adoptă o asemenea poziție pentru că ar crede că această formă drastică de pedepsire nu ar servi prevenției mai bine decât detenţiunea. Majoritatea pare că acceptă ideea potrivită căreia detențiunea nu viață nu reprezintă o „grijă” mai serioasă și mai mare pentru potențialul făptuitor decât pedeapsa cu moartea. În opinia noastră, perspectiva respondenților nu este una fără fundament. Dimpotrivă, cel puțin în multe dintre cazurile care implică fapte ce ar putea atrage cea mai severă pedeapsă, indiferent care ar fi aceasta, făptuitorul s-ar afla într-o situație în care să realizeze o analiză efectivă a argumentelor în care să ia în calcul inclusiv abandonarea planului infracțional doar pentru că ar însemna să fie supus uneia sau alteia dintre posibilele pedepse. Sunt de actualitate în acest sens cuvintele lui Albert Camus, care arăta că ,nu este dovedit că există vreun caz în care cineva decis să ucidă să se fi răzgândit din cauza pedepsei cu moartea, în timp ce este limpede că, dincolo de lipsa efectului scontat, fascineaz mii de criminali,"32.

Un număr mai mare de persoane, în schimb, au luat în calcul funcția educativă a pedepsei. Aparent, aceasta este relevantă și trebuie urmărită în contextul dezbaterii pentru aproximativ jumătate dintre respondenţi. Încercând să evităm speculațiile, nu ne putem înfrâna totuși de la a prezuma că persoanele care nu au luat în calcul acest argument ar fi procedat în acest mod deoarece ar considera că o asemenea îndreptare a condamnatului pare a fi utopică în multe cazuri care ar prezenta gravitatea necesară aplicării unor asemenea pedepse.

În al treilea rând, ne vom îndrepta atenția asupra celor două argumente care au atras cele mai multe răspunsuri, respectiv cel privind caracterul ireversibil al pedepsei capitale și cel privind inviolabilitatea absolută a dreptului fundamental la viață.

\footnotetext{
${ }^{31}$ Pentru o expunere amplă asupra studiilor efectuate în Statele Unite ale Americii în legătură cu funcția preventivă a pedepsei cu moartea, prin comparație cu cea a detențiunii pe viață, a se vedea M. Radelet, R. Akers, Deterrence and the Death Penalty: The Views of the Experts, în Journal of Criminal Law and Criminology, volume 87, issue 1, 1996, pag. 1-16.

${ }^{32}$ A se vedea A. Camus, în A. Koestler, A. Camus, Reflecții asupra pedepsei cu moartea, Ed. Humanitas. București, 2008, p. 123.
} 
Evident, nu putem ignora faptul că acest chestionar a fost adresat unor studenți la Drept. Aceasta poate fi una dintre explicațiile importante pentru care motivul ,nimeni, nici statul, nu are dreptul să suprime viața unei alte persoane" a fost ales de un număr mare de respondenți. Desigur, acest motiv este unul ce aparține, esențialmente, domeniului protecției drepturilor omului. Dreptul la viață este protejat la nivel de prim rang prin diverse instrumente internaționale, începând cu Pactul internațional cu privire la drepturile civile și politice și continuând, printre altele, cu Convenția pentru apărarea drepturilor omului și a libertăților fundamentale (cunoscută sub denumirea „Convenția europeană a drepturilor omului”). Desigur, în afara contextului juridic, acest argument poate fi privit și într-o paradigmă quid pro quo, însemnând că obligația impusă de stat cetățenilor de a nu atenta la viața altei persoane implică şi obligația statului de a acționa în acelaşi mod.

În fine, argumentul care a întrunit cele mai multe opțiuni este cel privind caracterul ireversibil al pedepsei capitale, poate cel mai pragmatic argument. ${ }^{33}$ Intr-o manieră subtextuală, acest argument trimite la cel al potențialului de existență a unor erori judiciare. ${ }^{34}$ In esență, optica este aceea că, dacă persoana a fost condamnată la o pedeapsă cu închisoarea, indiferent de durată, situația mai poate fi încă îndreptată, deși unele cazuri întâmplate chiar în țara noastră dovedesc contrariul ${ }^{35}$. Una din întrebările care s-ar putea naște în acest context este: înseamnă această împrejurare că cei mai mulți dintre studenți nu au încredere în capacitatea sistemului judiciar de a evita erorile? Credem că, deși nu putem vorbi despre o lipsă generală de încredere, în cele din urmă, o asemenea perspectivă nu reprezintă decât dovada unui anumit tip de realism. Trebuie să recunoaștem că, inclusiv în stadiul actual de dezvoltare, existența unui sistem judiciar fără erori este (încă) utopică.

Însă, un asemenea argument comportă și alte interpretări. În general, în legătură cu subiectul pedepsei cu moartea, persoanele analizează potențialele erori judiciare din perspectiva extremelor, respectiv o hotărâre netemeinică de condamnare într-o situație de nevinovăție ori o hotărâre netemeinică de achitare într-o situație de vinovăție. Noțiunea de eroare judiciară poate fi privită și într-o formă mai nuanțată. Este cel puțin dificil de imaginat un sistem legislativ în care un număr limitat și clar definit de infracțiuni să presupună exclusiv pedeapsa cu moartea, neexistând nici măcar posibilitatea ca, în anumite circumstanțe, să fie aplicată o altă pedeapsă (de exemplu, detențiunea pe viață). Astfel, există posibilitatea de a întâlni cauze în care persoana condamnată este într-adevăr vinovată de săvârșirea unei infracțiuni grave, dar în care, totodată, să se nască în mod serios întrebarea privind pedeapsa adecvată, fie una capitală, fie una privativă de libertate, indiferent de durată. Este drept în asemenea situații ca, efectiv, viaţa condamnatului, nu un anumit număr de ani, să depindă de eventualele perspective personale sau preferințe, chiar rezultate din convingeri intime, ale judecătorului sau ale forului care ar

\footnotetext{
33 În sensul supremației acestui argument, a se vedea Vincent Jones, The Problem with Capital Punishment: A Critical Assesment of the Ultimate Punitive Sanction, în University of Miami Law Review, volume 69, 2015, pag. 27-37.

${ }^{34}$ De exemplu, 12 astfel de cazuri de potențiale erori judiciare în cazul cărora s-a aplicat pedeapsa cu moartea sunt expuse în Rob Warden, Reflections on Capital Punishment, în Northwestern Journal of Law and Social Policy, volume 4, issue 2, 2009, pag. 329-359.

${ }^{35}$ A se vedea cazul Țundrea: https://www.mediafax.ro/social/tundrea-cel-mai-nedrept-caz-din-istoria-justitiei-inromania-in-timp-ce-nevinovatul-a-stat-in-puscarie-12-ani-adevaratul-criminal-va-fi-eliberat-dupa-cinci-ani-deinchisoare-16734366
} 
urma să stabilească pedeapsa? Nu putem nega faptul că persoanele chemate să îndeplinească funcția de jurisdictio sunt oameni cu convingeri, păreri, sentimente diverse. Finalmente, există posibilitatea ca viața unei persoane să depindă de un sistem aleatoriu de repartizare a cauzelor. Concluzionând asupra acestui capitol, constatăm un nivel rezonabil spre înalt de maturitate și raționalitate a selecției argumentelor. Desigur, discuția poate și va rămâne deschisă asupra ierarhiei motivelor ce stau la baza renunțării la pedeapsa capitală, neavând nici pretenţia de a epuiza în chestionarul nostru și în analiza subsecventă toate argumentele care pot fi aduse în dezbatere.

\section{B. Alternativele acceptate pentru pedeapsa cu moartea în cazul celor mai grave infracțiuni}

O primă trăsătură ce iese în evidență în legătură cu întrebarea „În absența pedepsei cu moartea, care credeți că ar trebui să fie cea mai aspră pedeapsă prevăzută de lege?" este, probabil, aceea că face legătura dintre subiectul punctual al pedepsei capitale și subiectul mult mai amplu, practic domeniul de sine stătător al penologiei. Într-adevăr, întrebarea invită la o explorare a formelor cele mai adecvate de pedepsire a celor mai grave infracțiuni, desigur, cu excluderea a priori a pedepsei capitale.

Totodată, o asemenea întrebare, privind-o exclusiv în legătură cu subiectul principal al chestionarului, oferă o perspectivă indirectă asupra ariei de extindere a aplicabilității argumentelor care conduc persoanele să se poziționeze împotriva pedepsei cu moartea. Vom dezvolta constatările asupra acestui aspect în secţiunea a treia a prezentului capitol.

$\mathrm{Nu}$ în ultimul rând, dar în mod limitat, întrebarea indică și o anumită măsură în care societatea înclină spre o asprime ridicată a pedepselor sau consideră că și pedepse mai puțin aspre pot asigura funcția preventivă a sancțiunii.

Constatări statistice. La întrebarea ,În absența pedepsei cu moartea, care credeți că ar trebui să fie cea mai aspră pedeapsă prevăzută de lege?”, studenții au putut opta între mai multe răspunsuri.

Desigur, în cazul acestei întrebări, respondenții au putut alege numai un singur răspuns. În total, 1528 de persoane au răspuns acestei întrebări, respectiv acele persoane care au răspuns „Nu” la întrebarea „Sunteți de acord cu aplicarea pedepsei cu moartea?”. Rezultate generale sunt reprezentate grafic în figura de mai jos (Figura 19). 
Fig. 19. Alternative acceptate pentru pedeapsa cu moartea

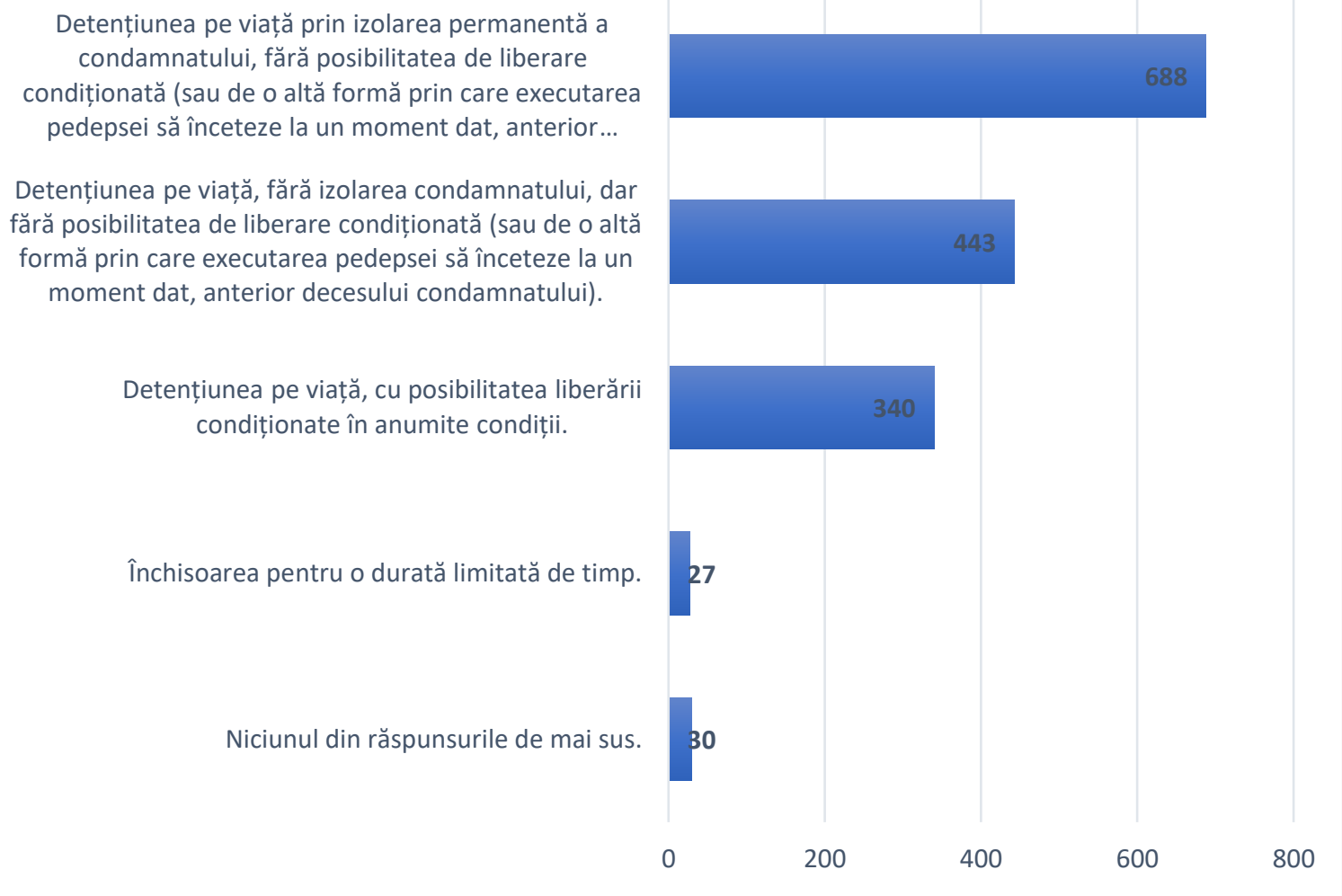

În primul rând, credem că se cuvine să amintim, fără a insista asupra sa, numărul de persoane care au arătat că nu pot opta pentru niciunul dintre răspunsurile posibile, respectiv 30 de respondenţi, corespunzători unui procent de $1,96 \%$. Pe de o parte, numărul este suficient de mic pentru a nu fi unul relevant. Pe de altă parte, persoanele care au ales acest răspuns au avut posibilitatea de a indica explicit alternativa preferată, iar răspunsurile nu sunt unitare nici măcar între cei 30 de respondenți. ${ }^{36}$

În al doilea rând, constatăm procentul deosebit de mic al persoanelor chestionate care au optat pentru pedeapsa cu închisoarea pentru o durată limitată în timp. Astfel, numai 27 de persoane, reprezentând $1,77 \%$ din total, au indicat această variantă.

În schimb, la polul opus, aproape jumătate dintre cei chestionați au optat pentru cea mai dură alternativă la pedeapsa cu moartea, una care, așa cum vom vedea în secțiunea următoare, are chiar deosebit de puține elemente de diferențiere față de pedeapsa capitală. 688 de persoane, reprezentând 45,03\% dintre respondenți, au indicat că cea mai potrivită alternativă la pedeapsa cu moartea, în cazul celor mai grave infracțiuni, este detențiunea pe viață prin izolarea permanentă a condamnatului, fără posibilitatea de liberare condiționată (sau de o altă formă prin care executarea pedepsei să înceteze la un moment dat, anterior decesului condamnatului).

\footnotetext{
${ }^{36}$ Numai cu titlu de exemplu, arătăm că printre răspunsurile alternative ale acestor persoane am identificat următoarele: „Detentiunea pe viață cu izolarea condamnatului, dar cu posibilitatea de liberare condiționată după o perioadă determinată de timp”; „Obligarea persoanelor la muncă neremunerată, în folosul comunitătiii”; „Deținuții ar trebui să fie închiși pe o insulă unde să existe plantații pe care aceștia să le ingrijească”; „Tortura (fizică, psihică)"; „Derogări de la anumite drepturi fundamentale".
} 
Celelalte persoane chestionate s-au împărțit între celelalte două variante. Astfel, 443 dintre respondenți, reprezentând $28,99 \%$ din total, au optat pentru detențiunea pe viață, fără izolarea condamnatului, dar fără posibilitatea de liberare condiționată (sau de o altă formă prin care executarea pedepsei să înceteze la un moment dat, anterior decesului condamnatului). 340 de persoane, reprezentând $22,25 \%$ din total, au optat pentru detențiunea pe viață, cu posibilitatea liberării condiționate în anumite condiții.

De asemenea, interesant este faptul că, ignorând variațiunea reprezentată de izolarea condamnatului, în total, 1131 dintre respondenţi apreciază că alternativa potrivită a pedepsei cu moartea ar trebui să fie detențiunea pe viață fără posibilitatea de liberare condiționată. Acest număr reprezintă $74,02 \%$ din totalul celor care nu sunt de acord cu pedeapsa cu moartea.

Un alt calcul conduce la o altă concluzie statistică interesantă. Raportându-ne la totalul respondenților (incluzându-i și pe cei care s-au declarat în favoarea pedepsei cu moartea), numai $18,03 \%$ dintre persoanele chestionate cred că o persoană care a săvârșit o faptă dintre cele mai grave ar mai trebui să aibă posibilitatea de a beneficia de liberare la un moment dat.

În legătură cu această întrebare, nu am identificat diferențe majore sau relevante între cele șapte facultăţi de drept care au participat la prezentul studiu. În cazul tuturor identificăm un procent mare al respondenților care optează pentru detențiunea pe viaţă, prin izolarea permanentă a condamnatului, fără posibilitatea de liberare condiționată, și un procent relativ mic al celor care optează pentru detențiunea pe viață, cu posibilitatea liberării condiționate.

O întrebare subsecventă i-a vizat numai pe cei care la întrebarea prezentată anterior au optat pentru răspunsul ,închisoarea pentru o durată limitată de timp”. Formularea acesteia a fost următoarea: „În opinia dumneavoastră, durata maximă a închisorii ar trebui să fie...”. Răspunsurile sunt redate în figura de mai jos (Figura 20).

\section{Fig. 20. Durata maximă a închisorii}

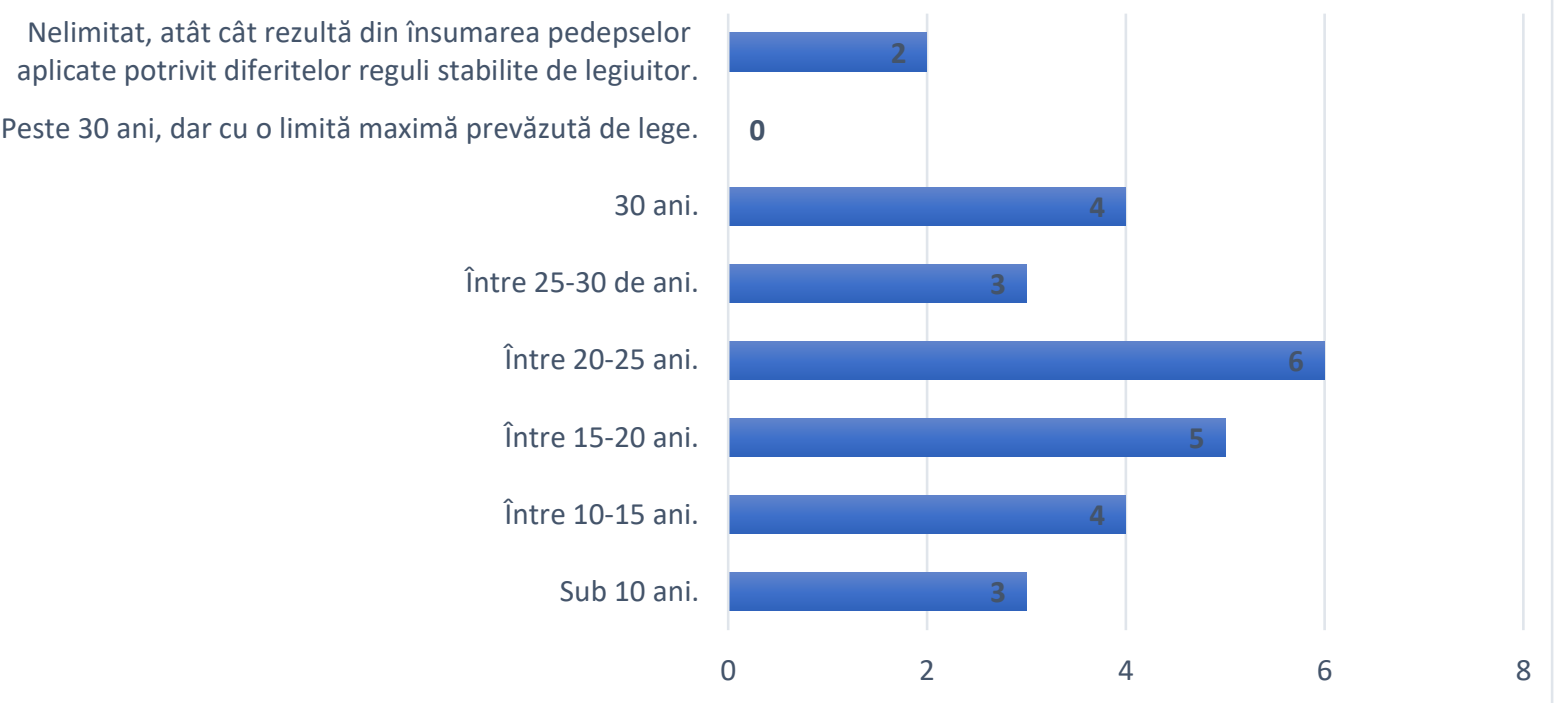

Desigur, în raport de numărul mic al celor care, în raport de întrebarea anterioară, au putut răspunde acestei întrebări, s-ar putea argumenta că procentele rezultate nu sunt unele deosebit 
de relevante. Totuși, chiar și în condițiile unui total de 27 de răspunsuri, credem că se cuvine să prezentăm situația răspunsurilor oferite.

Ne exprimăm speranța ca un studiu viitor să abordeze în mod direct problema pedepsei închisorii. În condițiile unui asemenea chestionar, una dintre întrebări ar putea să vizeze limitele pe care le au în vedere respondenții pentru diferite categorii de infracțiuni, rezultând concluzii cu siguranță mai relevante în ipoteza posibilității efective a tuturor de a-și exprima opinii în această direcție.

Comentarii analitice. $A b$ initio, arătăm că demersul de comparare a răspunsurilor oferite acestei întrebări cu răspunsurile oferite întrebării anterioare oferă poate cele mai interesante constatări.

În primul rând, observăm că aproximativ $96 \%$ dintre respondenți au selectat o formă de detențiune pe viață. Dintre aceștia, aproximativ 45\%, așadar aproximativ jumătate, au indicat detențiunea pe viață, cu izolarea condamnatului și fără posibilitatea de liberare condiţionată. În acelaşi timp, amintim faptul că un mare număr dintre respondenți, aproximativ $72 \%$, au indicat drept motiv de poziționare împotriva pedepsei cu moartea un argument aparținând domeniului drepturilor omului (inviolabilitatea absolută a dreptului la viaţă). În aceste împrejurări, se naște întrebarea: cum se încadrează mai bine în rigorile drepturilor omului detențiunea pe viață, cu izolare permanentă și fără posibilitate de liberare condiționată? Pe de altă parte, cum și-ar putea atinge o asemenea pedeapsă funcția educativă dacă cel condamnat nu ar putea previziona niciun beneficiu concret din eventualele sale demersuri de îndreptare?

$\mathrm{Nu}$ putem trece cu vederea nici faptul că, în total, aproximativ 74\% dintre respondenţi au selectat drept alternativă detențiunea pe viață, fără posibilitatea de liberare condiţionată, chiar dacă răspunsurile diferă asupra măsurii izolării condamnatului. ${ }^{37}$

Amintind apartenența subiectului la domeniul drepturilor omului, se cuvine să amintim şi poziţia Curții europene a drepturilor omului asupra acestui subiect. În cauza Vinter şi alții c. Regatului Unit, Marea Cameră a statuat următoarele: „Curtea apreciază că, în contextul unei detenţiuni pe viață, art. 3 trebuie interpretat în sensul de a impune posibilitatea de reducere a pedepsei, în sensul existenței unui mecanism de verificare care să permită autorităților naționale să analizeze dacă anumite schimbări în viața condamnatului sunt atât de semnificative și anumite progrese înspre reabilitare au fost făcute în cursul executării încât să conducă la concluzia că detenția nu mai este justificată și întemeiată pe temeiuri penologice legitime." 38

În aceste condiții, subsecvent, constatând totuși aplecarea respondenților spre o formă de pedepsire contrară chiar standardelor Curții europene a drepturilor omului, o nouă întrebare se naște: sunt studenții la Drept influențați de o formă de populism în domeniul dreptului penal? Cunoaștem, desigur, că nici domeniul legislației penale nu se poate păstra neatins de politici

\footnotetext{
37 Pentru e expunere amplă în susținerea detențiunii pe viață, fără posibilitatea de liberare condiționată, ca o alternativă optimă la pedeapsa cu moartea, a se vedea Julian Wright, Life-Without-Parole: An Alternative to Death or Not Much of a Life at All?, în Vanderbilt Law Review, volume 43, issue 2, 1990, pag. 529-568. Pentru o expunere amplă a argumentelor în sens contrar, a se vedea Michelle Miao, Replacing Death with Life? The Rise of LWOP in the Context of Abolitionist Campaigns in the United States, Northwestern Journal of Law and Social Policy, volume 15, issue 2, 2020, pag. 173-223.

${ }^{38}$ Curtea europeană a drepturilor omului, cauza Vinter și alții c. Regatului Unit, hotărârea Marii Camere din 9 iulie 2013, para. 119, hudoc.echr.coe.int.
} 
populiste. Iar un subiect preferat al ideilor populiste este imboldul de a stabili pedepse mai dure, mai lungi ${ }^{39}$.

Observăm că, deși majoritatea respondenților nu sunt de acord cu pedeapsa cu moartea, majoritatea celor care nu sunt de acord cu pedeapsa cu moartea par a nu fi de acord nici cu actualul sistem sancționator din România, poziționându-se, în esență, în favoarea unor pedepse chiar mai aspre decât cele existente în prezent.

$\mathrm{Cu}$ siguranță, subiectul modalităților optime de a pedepsi cele mai grave infracțiuni este unul care trebuie să preocupe legiuitorul și societatea, în ansamblul său. Însă, în egală măsură, credem că și subiectul evitării politicilor populiste în sistemul legislativ penal trebuie să reprezintă o arie de preocupare constantă.

\section{Aplicabilitatea pedepsei cu moartea în situații excepționale}

Este indubitabil faptul că situațiile excepționale și dificile, generate de diferiţi factori, de la pandemii la catastrofe naturale sau confruntări militare, modifică atât comportamentul răufăcătorilor, cât și comportamentul reactiv al societății. În general, protecția drepturilor și libertăților devine un deziderat mai greu de atins în contextul unei stări de urgență. Totodată, persoanele cu înclinații infracționale pot profita de un asemenea context și pot săvârși mai facil fapte antisociale dintre cele mai grave.

În condițiile unor asemenea împrejurări, asigurarea funcției preventive a pedepsei primește o importanță sporită. Din aceste motive, raportându-ne la subiectul principal al chestionarului, am apreciat că se impune adresarea unei întrebări privind aplicabilitatea pedepsei cu moartea în timpul unei stări de urgență. Scopul a fost acela de a afla dacă persoanele care în general nu ar fi de acord cu pedeapsa capitală și-ar schimba poziția luând în considerare împrejurări excepționale.

Constatări statistice. Având în vedere perioada în care chestionarul a fost aplicat (în plină stare de urgență determinată de pandemia CoVid-19), întrebarea adresată participanților a avut următoarea formulare: „Credeți că pedeapsa cu moartea ar trebui să rămână inaplicabilă inclusiv pentru fapte grave comise în timpul stării de urgență?" Desigur, similar întrebării principale a chestionarului, și aceasta a avut ca variante de răspuns numai „Da” sau „Nu”. Figura de mai jos (Figura 21) prezintă rezultatele analizei statistice a răspunsurilor acestei întrebări.

\footnotetext{
${ }^{39}$ A se vedea, pentru aceste aspecte V. Cioclei, 3p, un , virus" reactivat, care amenință sănătatea justiției penale, disponibil la adresa www.bizlawyer.ro.
} 


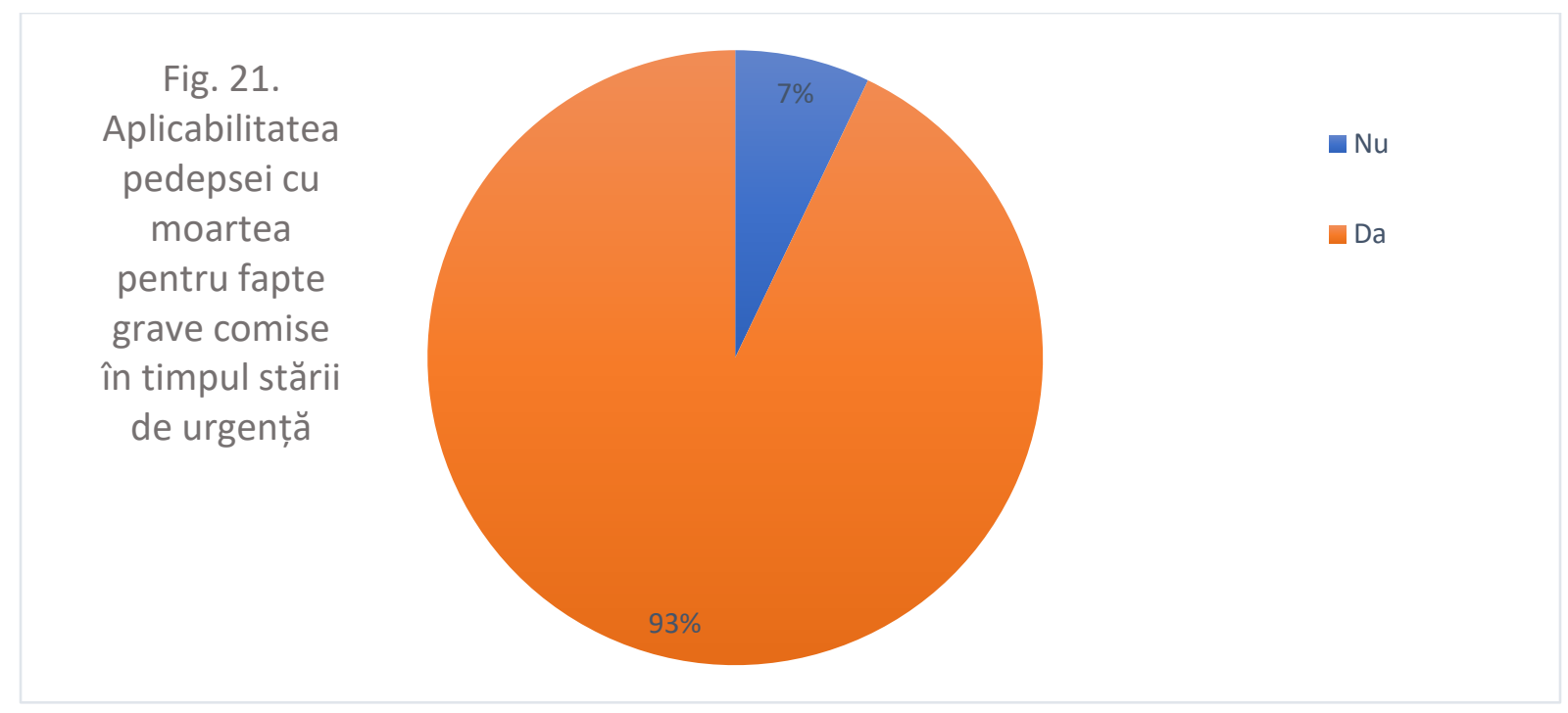

Se poate constata că un număr de 1399 din totalul de 1506 respondenți, așadar 92,9\%, au arătat că pedeapsa cu moartea nu ar trebui să fie aplicabilă nici pentru fapte grave comise în timpul stării de urgență. Totuşi, în condiţiile unei asemenea situaţii excepționale, 7,1\% dintre cei care, în general, nu sunt de acord cu pedeapsa capitală, cred că aceasta ar trebui să fie aplicată în cazul unor fapte grave $e^{40}$.

Consecința răspunsurilor date acestei întrebări este că procentul general de $69,42 \%$ respondenți care se poziţionează împotriva pedepsei cu moartea trebuie ajustat. Observăm că, dintre aceștia, un procent (este adevărat, mic) se declară, totuși, de acord cu aplicarea pedepsei capitale. Astfel, anumite circumstanțe excepționale determină în cazul acestor persoane părăsirea argumentelor care, în general, îi situează contra pedepsei cu moartea.

Comentarii analitice. În privința acestei întrebări, desigur, comentariile și analizele ce se pot face sunt, din punct de vedere cantitativ, mai puține decât în cazul celor precedente. Concluzia matematică este una destul de simplă. Un număr relativ mic, dar semnificativ, de persoane, deși sunt, în general, împotriva pedepsei cu moartea, în anumite circumstanțe așază excepționalismul împrejurărilor deasupra argumentelor raționale obișnuite.

Dintr-un alt punct de vedere, se poate constata din nou că în aria persoanelor care nu sunt de acord cu pedeapsa cu moartea un număr semnificativ apreciază că nu este un motiv faptul că detențiunea ar avea o funcție preventivă mai pronunțată decât pedeapsa capitală. Dimpotrivă, având în vedere că în condițiile unei stări de urgență, cel mai important este ca societatea să prevină faptele antisociale, unii respondenți par să creadă că un eventual rol preventiv superior al pedepsei cu moartea ar impune posibilitatea aplicării acesteia.

\footnotetext{
${ }^{40}$ Procentul este dublu (14.3\%) în rândul studenților provenind de la alte facultăți din cadrul Universității din București. Reamintim însă că numărul respondenților a fost foarte mic, de 46.
} 


\section{CONCLUZIE}

Întrebarea firească ce se poate pune după lecturarea acestui studiu este: de ce am analizat din nou această problemă, cu toate că este deseori afirmat că numai societățile bolnave permit încă pedeapsa cu moartea ${ }^{41}$ ? Am dorit să analizăm care este poziția studenților la Drept asupra pedepsei capitale, de vreme ce, față de destinatarii recurenți ai acestor studii, participanții la chestionarul nostru au și studii de drept sau sunt în cursul finalizării acestora. $\mathrm{Cu}$ alte cuvinte, ne-am imaginat că este posibil ca aceștia să își fundamenteze opinia pe argumente de ordin juridic și raţional mai degrabă decât pe cele de ordin afectiv sau emoțional, cum se întâmplă poate în cazul majorității populaţiei. După cum se arată în mai multe studii, ,o mare parte a publicului - în Statele Unite și în alte părți - este ignorant cu privire la multe aspecte ale criminalității și controlul acesteia. (...) Dar în majoritatea celorlalte domenii - inclusiv cunoașterea tendințelor în ceea ce privește ratele penale, prevalența infracțiunilor violente, a ratelor recidive, a legilor penale specifice, a reformelor legale, a drepturilor legale in procesul de justiție penală - lipsa cunoștințelor este răspândită ${ }^{42 "}$, și ,,numai un public complet informat cu privire la scopurile pedepsei și la obligațiile sale ar considera pedeapsa șocantă, nedreaptă și inacceptabilă’. În plus, se menționează că ,înțelegerea oamenilor cu privire la severitatea și opțiunile condamnării este restricționată și deseori denaturată. De exemplu, nu este clar că cetățenii înțeleg ce sancțiuni, în afară de închisoare, pot fi acordate infractorilor și, dacă se distribuie alternative la incarcerare (de exemplu, probațiune, supraveghere intensivă a serviciului comunitar), ce presupun aceste sancțiuni comunitare”.

Rezultatele studiului nostru indică, totuși, că opinia studenţilor la Drept, deci a unor persoane presupuse a nu fi ignorante (în sensul celor menționate mai sus), având toate informațiile necesare pentru a decide în consecință, nu diferă atât de mult precum am prezumat inițial. Totuși, la sfârșitul studiului, putem observa că, dincolo de opțiunile predefinite pe care aceștia le-au ales, mulți studenți au ales să își dezvolte opinia în favoarea pedepsei cu moartea, oferind de cele mai multe ori argumente pertinente, cu legături criminologice și psihologice. În același sens, opțiunile celor care s-au poziționat contra pedepsei cu moartea au indicat o oarecare cunoaștere a sistemului judiciar. Având în vedere răspunsurile studenților, nu putem concluziona decât că subiectul aplicării pedepsei cu moartea rămâne unul deschis și în România, unde de fiecare dată când o crimă cu impact mediatic puternic va fi comisă, dar și când o persoană eliberată condiționat va săvârși o nouă infracțiune, se va pune problema, cel puţin în cadrul opiniei publice, dacă nu ar fi mai potrivită pedeapsa cu moartea în locul unei eventuale detențiuni pe viață, de vreme ce, așa cum am văzut, condamnatul are minime șanse să mai fie reeducat.

În fine, este de remarcat că, spre deosebire de concluziile altor studii citate în această lucrare, nu putem afirma că motivele numărului însemnat de studenți care susțin pedeapsa cu moartea țin de percepția unui nivel ridicat al criminalității ori de un eventual sentiment de insecuritate socială. Iar această concluzie arată că opinia publică cu privire la necesitatea

\footnotetext{
${ }^{41}$ A se vedea R. Badinter, Contre la peine de mort, Libraire Artheme Fayard, 2006, p. 28.

${ }^{42}$ Pentru un rezumat al cercetărilor, a se vedea Roberts J.V. 1992. Public opinion, crime and criminal justice, in Crime and Justice. A Review of Research, vol. 16, ed. M. Tonry. The University of Chicago Press, Chicago; Roberts, J.V. \& Stalans, L. 1997. Public Opinion, Crime, and Criminal Justice. Westview Press, Colorado.
} 
introducerii pedepsei cu moartea nu este în mod necesar legată de contextul economic, politic sau social, și deschide, deci, subiectul pentru viitoare cercetări referitoare la etiologia susținerii acestei pedepse.

*Materialul a fost publicat în AUBD-Forum Juridic nr. 3/2020. 